\title{
Article \\ Spatial-Temporal Characteristics of Coastline Changes in Indonesia from 1990 to 2018
}

\author{
Lichun Sui ${ }^{1}$, Jun Wang ${ }^{1}$, Xiaomei Yang ${ }^{2,3,4, *(1)}$ and Zhihua Wang ${ }^{2,3(1)}$ \\ 1 Geological Engineering and Institute of Surveying and Mapping, Chang'an University, Xi'an 710054, China; \\ sui1011@chd.edu.cn (L.S.); 2017026007@chd.edu.cn (J.W.) \\ 2 State Key Laboratory of Resources and Environment Information System, Institute of Geographic Sciences \\ and Natural Resources Research, Chinese Academy of Sciences, Beijing 100101, China; zhwang@lreis.ac.cn \\ 3 University of Chinese Academy of Sciences, Beijing 100049, China \\ 4 Jiangsu Center for Collaborative Innovation in Geographical Information Resource Development and \\ Application, Nanjing 210023, China \\ * Correspondence: yangxm@lreis.ac.cn; Tel.: +86-10-6488-8955
}

Received: 11 March 2020; Accepted: 14 April 2020; Published: 16 April 2020

check for

Abstract: As a valuable resource in coastal areas, coastlines are not only vulnerable to natural processes such as erosion, siltation, and disasters, but are also subjected to strong pressures from human processes such as urban growth, resource development, and pollution discharge. This is especially true for reef nations with rich coastline resources and a large population, like Indonesia. The technical joint of remote sensing (RS) and geographic information system (GIS) has significant advantages for monitoring coastline changes on a large scale and for quantitatively analyzing their change mechanisms. Indonesia was taken as an example in this study because of its abundant coastline resources and large population. First, Landsat images from 1990 to 2018 were used to obtain coastline information. Then, the index of coastline utilization degree (ICUD) method, the changes in land and sea patterns method, and the ICUD at different scales method were used to reveal the spatiotemporal change pattern for the coastline. The results found that: (1) Indonesia's total coastline length has increased by $777.40 \mathrm{~km}$ in the past 28 years, of which the natural coastline decreased by $5995.52 \mathrm{~km}$ and the artificial coastline increased by $6771.92 \mathrm{~km}$. (2) From the analysis of the island scale, it was known that the island with the largest increase in ICUD was Kalimantan, at the expense of the mangrove coastline. (3) On the provincial scale, the province with the largest change of ICUD was Sumatera Selatan Province, which increased from 100 in 1900 to 266.43 in 2018. (4) The change trend of the land and sea pattern for the Indonesian coastline was mainly expanded to the sea. The part that eroded to the land was relatively small; among which, Riau Province had the most significant expansion of land area, about $177.73 \mathrm{~km}^{2}$, accounting for $23.08 \%$ of the increased national land area. The worst seawater erosion was in the Jawa Barat Province. Based on the analysis of population and economic data during the same period, it was found that the main driving mechanism behind Indonesia's coastline change was population growth, which outweighed the impact of economic development. However, the main constraint on the Indonesian coastline was the topographic factor. The RS and GIS scheme used in this study can not only provide support for coastline resource development and policy formulation in Indonesia, but also provide a valuable reference for the evolution of coastline resources and environments in other regions around the world.

Keywords: coastline; Indonesia; remote sensing; change monitoring; GIS

\section{Introduction}

The coastline is the boundary between sea and land contact [1], an important base and carrier for human survival and development, and a special natural resource [2]. It features include 
instability [3-7], functional diversity [8], regional difference [9,10], and other important features. From the twentieth century, coastal countries have turned their economic development centers to coastal areas, and nearly $50 \%$ of the global population has settled in areas within $100 \mathrm{~km}$ of the coastline [11]. However, the transfer of economic centers has caused rapid changes in coastline resources, which has had a huge impact on the economic, social, ecological, and environmental aspects of coastal areas [12]. For example, large-scale reclamation projects have greatly reduced the proportion of natural coastlines [13]. The excessive use of coastlines, artificial correction of naturally curved coastlines, and disorderly aquaculture has degraded the ecological environment of coastal areas. With the continuous development of marine resources, the coastal zone will become a key area for coastal economic development. Monitoring coastline changes is an effective way to study the environmental and ecological changes of the coastal zone. Therefore, monitoring the coastline has become an important task for sustainable development and environmental protection [14,15].

At present, remote sensing (RS) image-based methods have become common for monitoring coastline changes due to their large coverage and low cost [16-22]. Many scholars have researched coastline changes, and the potential causes of these changes have been analyzed and recognized [23]. For example, Mishra et al. [24] evaluated the long-term to short-term dynamics of the coastline location of the Uri district in India over the past 25 years (1990-2015) by using open-access multi-temporal satellite imagery, deriving that the reason behind the changes as were human buildings and the erosion of coastlines. To clearly illustrate the impact of the dam construction on the delta, Kale et al. [25] studied the erosion rates and coastline variations on the Yesilirmak River in northern coastline of Turkey before 2017. Thoai et al. [26] studied the coastline changes of the Ca Mau Cape in Vietnam over the past 20 years and concluded that the most important factors affecting the coastline changes in the region were forest area loss, river dredging, and aquaculture and infrastructure development. Wu et al. [27] took the Shenzhen Special Economic Zone of China as an example to study the changes on coastline in the region from 1988 to 2015, and found that the characteristics of coastline stability were completely different between the eastern and western coastlines of Shenzhen, its regional differences were mainly reflected in the morphological changes and changing laws of the coastlines. Throughout the above studies, the research on coastline changes has been mainly focused on two aspects: firstly, that the characteristics of the spatiotemporal changes to the coastline are described by the rate of coastline change and the changes in the land and sea area caused by the coastline changes [28,29]; secondly, analyzing the characteristics and trends, whilst also exploring the influence of climate, geology, human activities, and other factors on coastline changes [30-33]. However, existing coastline research has mainly focused on smaller areas, such as bays and estuaries [34-36]. Their regional limitations have prevented the comparative analysis of large-scale long-term sequences [37]. Further, few studies have been conducted on the coastlines of island countries with more fragmented ground. Research on island coastlines has just begun in the twenty-first century [38].

Due to global warming and rising sea levels, the future development of islands faces serious threats $[39,40]$. Governments around the world are adopting various strategies to address the threat posed by rising sea levels and coastal flooding to coastal cities [41]. However, so far, most research has only focused on a few islands and atolls [42-44]. In the absence of large-scale island country research and data support, the spatial and temporal changes of island coastlines have not been well documented. Intuitively, the geographically fragmented island nations are the most vulnerable to seawater erosion and human activities, due to their open coasts and frequent land-water exchanges. But is this actually the case? If they are effected, what are the main effects of the change in their coastlines? Are they mainly affected by natural or human factors? What is the regional difference? The answers to these questions are of great reference value to understanding whether geo-fragmented island nations should actively respond to the ecological and environmental problems brought about by the coastline change, and, if necessary, how they should respond.

Indonesia is a typical archipelago country with rich coastline resources [45]. Its geographical location is at the crossroads of Asia and Oceania, and it sits on important straits for maritime 
transportation: the Malacca Strait, Lombok Strait, and Makassar Strait. However, it is because of the unique geographical location of the region that frequent disaster outbreaks have caused great damage to various types of resources in the coastal area. At present, many scholars' research on the area focus mostly upon the impact of resource and environmental damage causing by coastal disasters [46-48]. For example, Borrero et al. [49] conducted on site investigations of the tsunami that occurred in the Bengkulu Province of Sumatra, Indonesia in 2007, focusing on the destruction of coastline resources and casualties, and obtained relevant data for disaster prediction and simulation. Paulik et al. [50] observed buildings and environmental damage within $300 \mathrm{~m}$ of the coastline by using satellite images after the earthquake and tsunami disaster in Palu, Sulawesi. The results of the survey can provide a basis for future tsunami disaster and risk research in Indonesia. The above studies only examined disaster prediction and damage losses, but ignored the changes in coastline resources that were most directly damaged by the disaster. Some scholars also conducted coastline monitoring for the city of Semarang, Indonesia, and found that the changes in this area were mainly dominated by sedimentation $[51,52]$. However, the above studies only analyzed a small area and lacked the monitoring of national coastline changes. In recent years, Zhang et al. [38] have also analyzed the characteristics of coastline changes in large areas of Southeast Asian countries, and concluded that the coastline of Southeast Asia has remained relatively stable during 2000-2015, but has seen a large spatial change in estuaries, bays, and straits. Considering the particularity of Indonesia's geographic and climatic characteristics, few studies have conducted a comprehensive analysis of the coastline spatial changes on a relatively national scale, island scale, and inter-provincial scale over a long time period. Obtaining data on the coastline spatial changes at different scales in the region from 1990 to 2018 can provide important information for evaluating the development and ecological risks of the coastal areas of multi-island countries and help to more scientifically and rationally manage and protect the coastline.

Therefore, this paper took Indonesia as an example, and used remote sensing technology to quantify the development and utilization of the country's coastline resources and the spatial distribution of resources on different scales [53]. These achievements have guiding significance for assisting the geographically fragmented island nations that straddle multiple straits, waterways, and harbors to achieve optimal regional coastline resource allocation alongside economic development. It can provide basic support data for disaster prevention and control in Indonesia in response to the frequent disasters caused by climate change. Furthermore, this study can also provide reference for other island nations studying and responding to coastline environmental problems caused by natural and human factors.

\section{Study on the Area and Data Source}

\subsection{Study on the Situation of Area}

Indonesia is located in Southeast Asia and is mainly affected by the northern and southern equatorial currents, spanning the equator, longitude $96^{\circ}-140^{\circ} \mathrm{E}, 12^{\circ}-7^{\circ} \mathrm{N}$. It is the largest archipelago country in the world, consisting of approximately 17,508 islands between the Pacific and the Indian Ocean. The land area is about 1.904 million square kilometers and the ocean area is about 3.166 million square kilometers (excluding the exclusive economic zone) (Figure 1). Kalimantan Island in the north faces Malaysia across the sea, and New Guinea Island is connected to Papua New Guinea. The northeast faces the Philippines, the southwest is connected the Indian Ocean, and the southeast faces Australia. The islands of Indonesia are relatively scattered, including Kalimantan, Sumatra, Papua, Sulawesi, and Java. There are rugged mountains and hills in the interior of the islands, with narrow plains only along the coast, and they are surrounded by shallow seas and corals. On Kalimantan Island, the mountains stretch from the middle to the west, the coastal plain is vast, and the south is swampy. For Sumatra, the mountains run diagonally from northwest to southeast. To the northeast side of the mountains are hills and a wide coastal alluvial plain. The plains are swampy in the east. Sulawesi, mostly mountainous, has narrow plains only along the coast. Java has a plain in the north and a lava plateau and mountains in the south. Papua Island, with high mountains in 
the west, has the highest peak in Indonesia, Chaya Peak, with an altitude of $5030 \mathrm{~m}$. The southern plain is relatively wide. Indonesia is a typical tropical rain forest climate, with an average annual temperature of $25-27^{\circ} \mathrm{C}$, and no seasonal differences. The north is affected by the monsoon in the northern hemisphere, and precipitation is abundant in July-September. The south is affected by the monsoon in the southern hemisphere; precipitation is rich in December, January, and February, and the annual precipitation is $1600-2200 \mathrm{~mm}$.

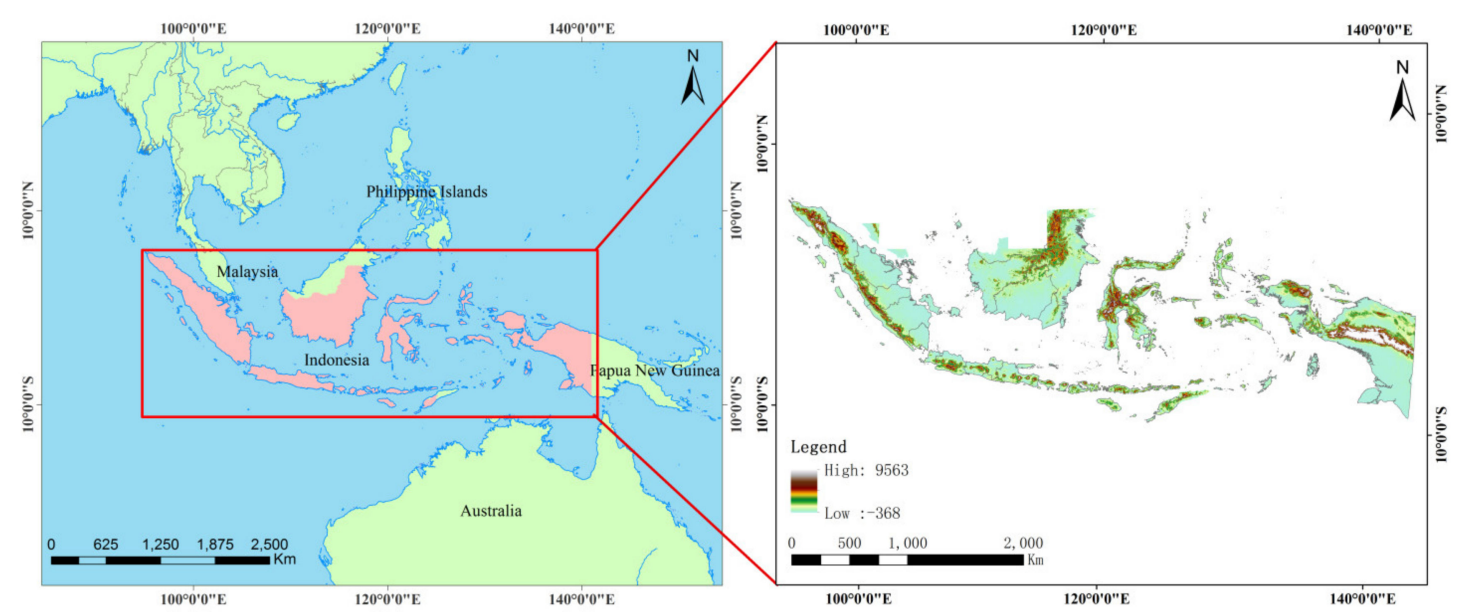

Figure 1. Geographical location and elevation map of Indonesia.

\subsection{Data Source and Preprocessing}

In this study, Landsat Thematic Mapper (TM) and Operational Land Imager (OLI) remote sensing images obtained in 1990 and 2018 were used as the basic data sources. All of these were downloaded freely from the website (http://glovis.usgs.gov). In order to study the spatial and temporal changes of the Indonesian coastline in the past 28 years, this study collected 168 scenes from each period of the Landsat TM/OLI images of the Indonesian coastline, and a total of 336 scenes in the two periods (images had less than 20\% cloud content). The imaging times were around 1990 and 2018, respectively. Because of the larger image data, these are no longer listed in detail in this article. Due to Indonesia's land spans the equator, remote sensing images were projected into the Mercator projection coordinate system during preprocessing.

In addition, in order to further analyze the potential ecological and environmental problems caused by coastline changes, we collected the elevation data of the Indonesia region from the geospatial data cloud (http://www.gscloud.cn/), with a spatial resolution of $90 \mathrm{~m}$. This was further resampled to $30 \mathrm{~m}$ in ArcGIS 10.2. In order to uncover the changes in coastline erosion and sedimentation, economic and population data were used to conduct the drive analysis. We also obtained data from the World Bank's public data (https://data.worldbank.org.cn/) and the Indonesian Central Statistical Office (https://www.bps.go.id/) for collecting Indonesia's Gross Domestic Product (GDP) and population data from 1900 to 2018, as well as population data for each province.

\section{Method}

\subsection{Extraction and Classification of Coastline}

There are many standards for the definition of coastlines. In order to facilitate unified standards for monitoring remote sensing change, the default coastline in this article is the instantaneous waterline [54]. Esmail et al. [55] have compared and analyzed the three methods of squared-error clustering method, threshold, and screen digitization, and concluded that squared-error clustering was the best method for coastline extraction, but that traditional methods such as the visual interpretation of human-computer interaction were still commonly used by experts to extract coastal information [56]. Therefore, this paper adopted the method of human-computer interactive visual interpretation. Firstly, ENVI5.2 [57] 
software was used to preprocess the remote sensing images, including geometric correction, image registration, and image stitching. Most of the images were systematically and geometrically corrected. The geometric correction method of some images involved finding the points with the same name on the two images according to the gray value of the pixel or the feature of the ground. When selecting points, we attempted to distribute the entire image as evenly as possible. The points were mainly selected from easily distinguishable and finer feature points, such as road intersections and the edge of the city profile, and the maximum RMS error must be less than 1 . Then, the geometric correction of the two images were completed. On the basis of clarifying the different reflection spectrum characteristics of the features near the coastline, the remote sensing images were separated by normalized difference water index (NDWI) water and land after preprocessing [58], the boundary line was enhanced, and the exact location of the instantaneous water edge was extracted by Otsu'sthreshold segmentation method [59].

The classification of the obtained coastline was mainly based on knowledge obtained by Google Earth images and field surveys; then, the digitization of topographic maps and the visual interpretation of remote sensing images were classified. Concerning the classification details of coastline, we first obtained the instantaneous waterline of the image, and then defined the coastline type on the land cover type on the image within a range of $100 \mathrm{~m}$ (3 pixels) along the instantaneous waterline. For the coastlines with more complicated land cover types in this range, we adopted the principle of the largest area of land cover types within a range of $100 \mathrm{~m}$, that is, the land area of a certain land use type had the largest area ratio, which was the coastline classification of this type. After classification according to this standard, the consistency of the extracted coastline was good. In particular, the comparison of the two periods could eliminate as much as possible the inconsistency of the standards, which would have caused deviations in the analysis of coastline changes in the two periods. During 2019, we conducted a field survey covering the coast of Indonesia, and after 14 people had travelled across $1559.97 \mathrm{~km}^{2}$, we finally obtained more than 4000 live photos. Based on comprehensive research results [3,60-63], the Indonesian coastline was divided into two primary category types, natural coastline and artificial coastline. The natural coastline was further divided into bedrock coastline, silt coastline, mangrove coastline, and sandy coastline; the artificial coastline was further divided into harbor and wharf, embankment, and agricultural, with a total of seven secondary categories types (Table 1). The corresponding coastline types were displayed on the Landsat image in 543 bands combined with false color display (Figure 2), and finally the coastline classification was achieved by human-computer interactive visual interpretation. The specific processing flow is shown in Figure 3.

Table 1. Indonesia coastline categories.

\begin{tabular}{|c|c|c|}
\hline Primary Categories & Secondary Categories & Description \\
\hline \multirow{4}{*}{ Natural coastline } & Bedrock coastline & $\begin{array}{c}\text { The coastline is tortuous, the waterway is clearly demarcated, } \\
\text { and the tone is darker }\end{array}$ \\
\hline & Silt coastline & $\begin{array}{c}\text { Beach broad smooth surface, to the roadside vegetation lush, } \\
\text { sparse vegetation seaward side }\end{array}$ \\
\hline & Mangrove coastline & $\begin{array}{c}\text { Distributed in pieces, mostly branch-like water systems, reddish } \\
\text { hue, brighter than land vegetation }\end{array}$ \\
\hline & Sandy coastline & $\begin{array}{l}\text { Generally composed of loose, very soft, very fine materials such as } \\
\text { sand, silt, and sludge, consisting of relatively straight coastline } \\
\text { and relatively wide, relatively long beaches, there is generally } \\
\text { sand in the bay at high tide }\end{array}$ \\
\hline \multirow{4}{*}{ Artificial coastline } & Harbor and Wharf & Convex embankment, harbor pool markers, smooth texture \\
\hline & & The boundary between the outer edge of the sea, such as ports, \\
\hline & Embankment & $\begin{array}{l}\text { docks, storage land, towns, and industrial land, and the waterway } \\
\text { of the ocean is generally distributed on a large scale with certain } \\
\text { brightness, but this is not uniform. }\end{array}$ \\
\hline & Agricultural & A rectangular grid arrangement, color red, uniform texture \\
\hline
\end{tabular}



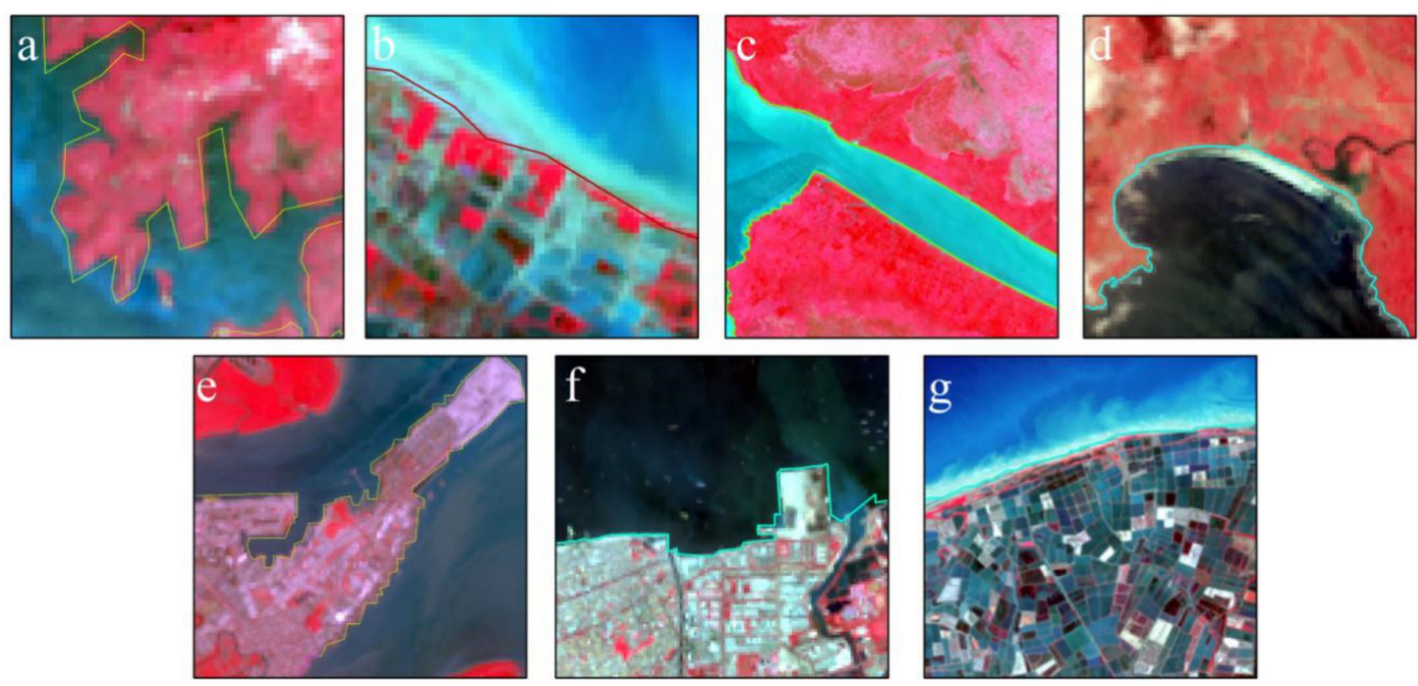

Figure 2. Landsat image interpretation sign of Indonesian coastline type: (a) Bedrock coastline; (b) Silt coastline; (c) Mangrove coastline; (d) Sandy coastline; (e) Harbor and Wharf; (f) Embankment; (g) Agricultural.

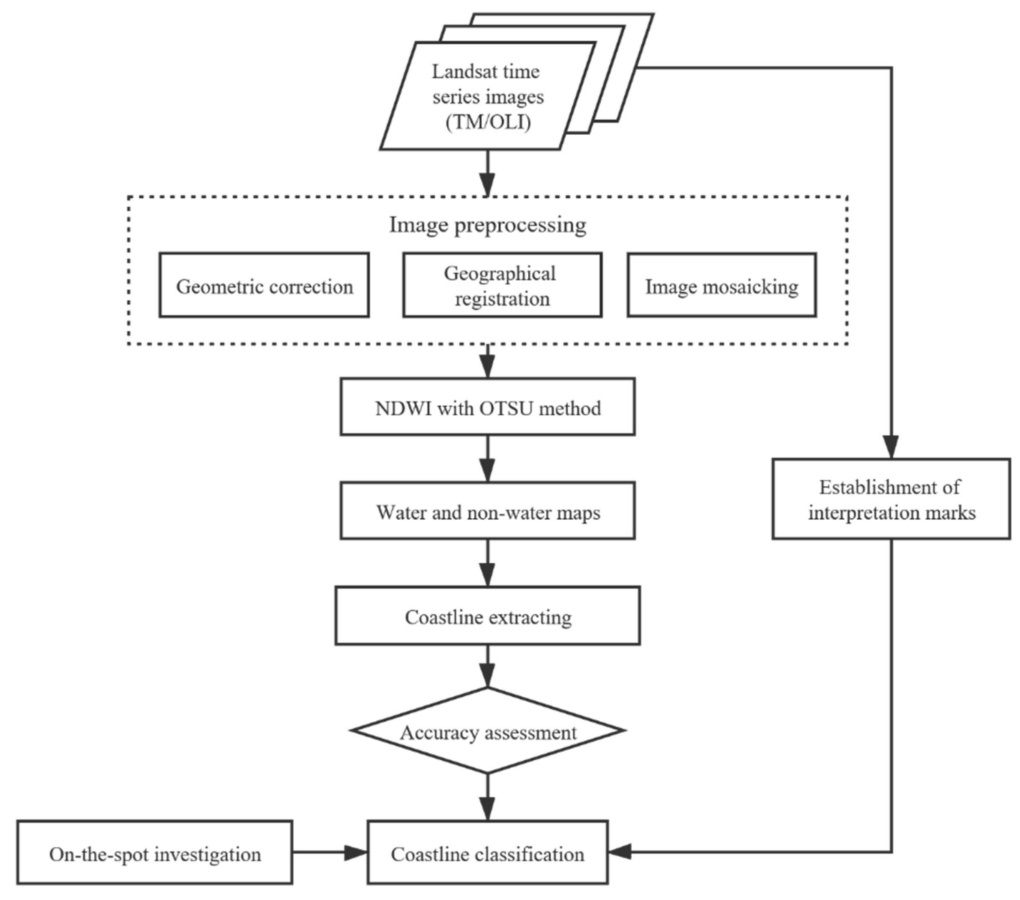

Figure 3. Flowchart of extraction and coastline classification. (Note: normalized difference water index (NDWI), OTSU is a threshold segmentation method proposed by Otsu.).

\subsection{Coastline Accuracy Evaluation}

The statistical method of manually selecting random points was used to evaluate the accuracy of the extracted coastline [64]. Because the coastline is long and the cost of doing many sampling tests was too high, in order to make the sample cover the entire area as much as possible when doing accuracy evaluation, we randomly selected three regions of Indonesia from west to east for representative inspections. In addition, because the standards we extracted were uniform and the data consistency of the entire region was good, we believe that it was feasible to use the accuracy of the detailed verifications instead of the overall accuracy evaluation. Firstly, we manually selected 300 points on the original image along the edge of the coastline (Figure 4). For each area we selected 300 points for each period of data, a total of 1800 points for accuracy evaluation. Then, we calculated the shortest 
distance from each random point to the extracted coastline. If the random point was inside the land, the distance value was positive; otherwise, it was negative. According to Table 2, the resolution of TM image and OLI image was $30 \mathrm{~m}$. Therefore, according to the statistical results of the histogram (Figure 5), in the two periods of 1990 and 2018, the proportions of random points selected from west to east in 1990 that were within one-pixel distance were $84.33 \%, 84.67 \%$, and $89.67 \%$, respectively, and in 2018 within one-pixel distance were $90.66 \%, 87.33 \%$, and $90.32 \%$, respectively. The extraction accuracy of the coastline met the study needs.

Table 2. Landsat TM/OLI band introduction.

\begin{tabular}{cccccc}
\hline Band Name & $\begin{array}{c}\text { Landsat } \mathbf{5} \\
\text { Band Width }(\boldsymbol{\mu m})\end{array}$ & Resolution $(\mathbf{m})$ & Band Name & $\begin{array}{c}\text { Landsat } 8 \\
\text { Band Width }(\boldsymbol{\mu m})\end{array}$ & Resolution(m) \\
\hline & & & Band 1 Coastal & $0.43-0.45$ & 30 \\
Band 1 Blue & $0.45-0.52$ & 30 & Band 2 Blue & $0.45-0.51$ & 30 \\
Band 2 Green & $0.52-0.60$ & 30 & Band 3 Green & $0.53-0.59$ & 30 \\
Band 3 Red & $0.63-0.69$ & 30 & Band 4 Red & $0.64-0.67$ & 30 \\
Band 4 NIR & $0.76-0.90$ & 30 & Band 5 NIR & $0.85-0.88$ & 30 \\
Band 5 SWIR & $1.55-1.75$ & 30 & Band 6 SWIR 1 & $1.57-1.65$ & 30 \\
Band 6 LWIR & $10.40-12.5$ & 120 & Band 7 SWIR 2 & $2.11-2.29$ & 30 \\
Band 7 SWIR & $2.08-2.35$ & 30 & Band 8 Pan & $0.50-0.68$ & 15 \\
& & & Band 9 Cirrus & $1.36-1.38$ & 30 \\
& & & Band 10 TIRS1 & $10.6-11.19$ & 100 \\
\hline
\end{tabular}

Note: The full name of the abbreviation Landsat TM/OLI is Thematic Mapper (TM) and Operational Land Imager (OLI).

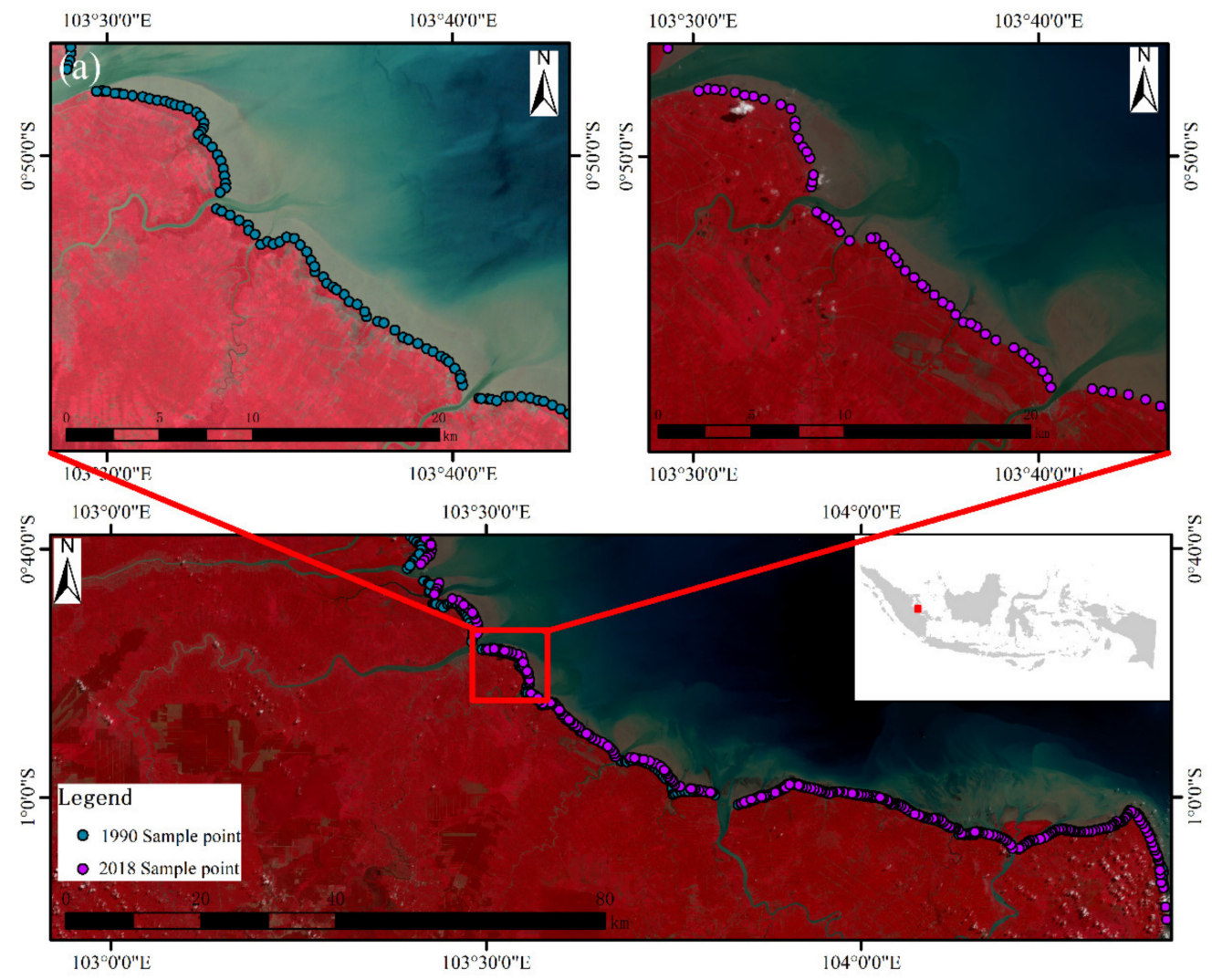

Figure 4. Cont. 

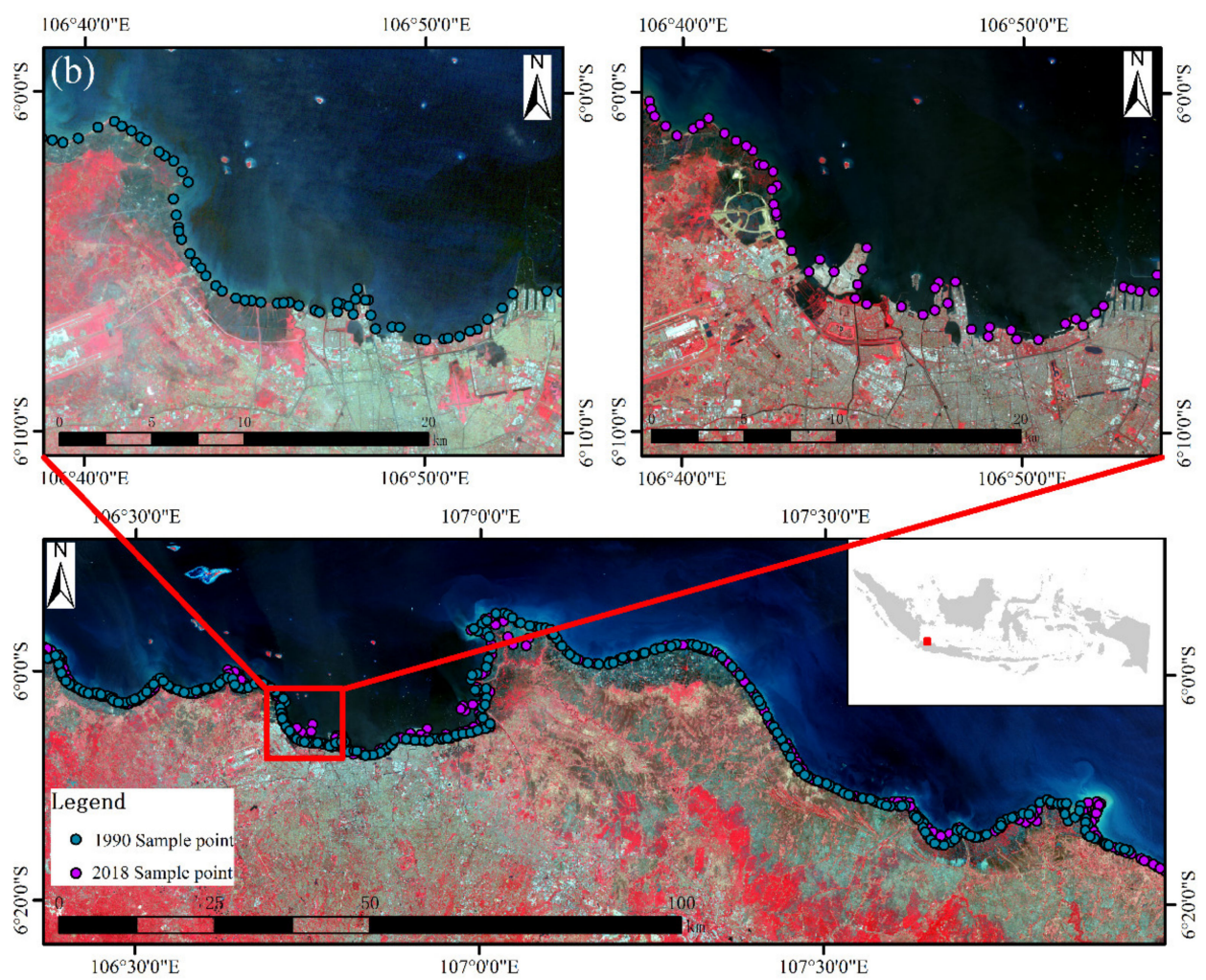

$122^{\circ} 10^{\prime} 0^{\prime \prime} \mathrm{E}$

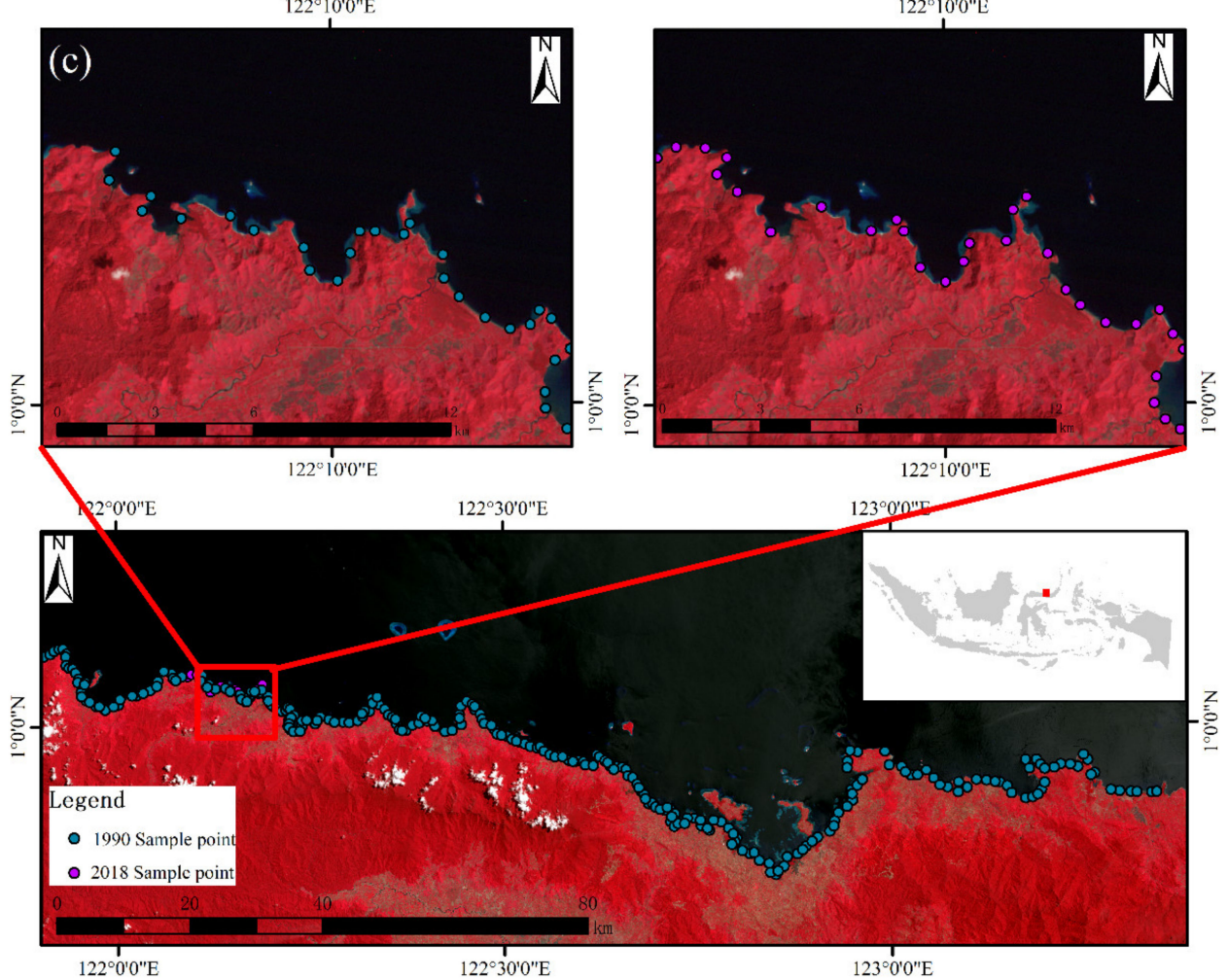

Figure 4. Verification of the sample point distribution map: (a) Verification area 1 is located near Sumatra; (b) Verification area 2 is located near Java; (c) Verification area 3 is located near Sulawesi. (Note: $(\mathbf{a}-\mathbf{c})$ are arranged from west to east). 


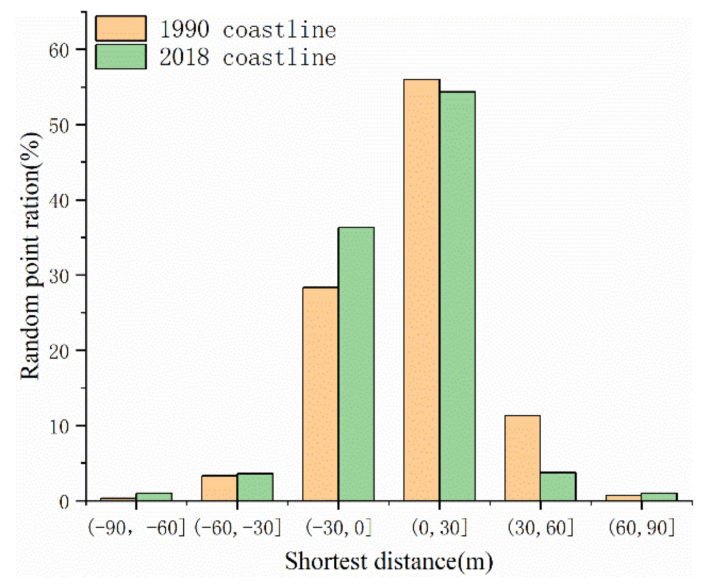

(a)

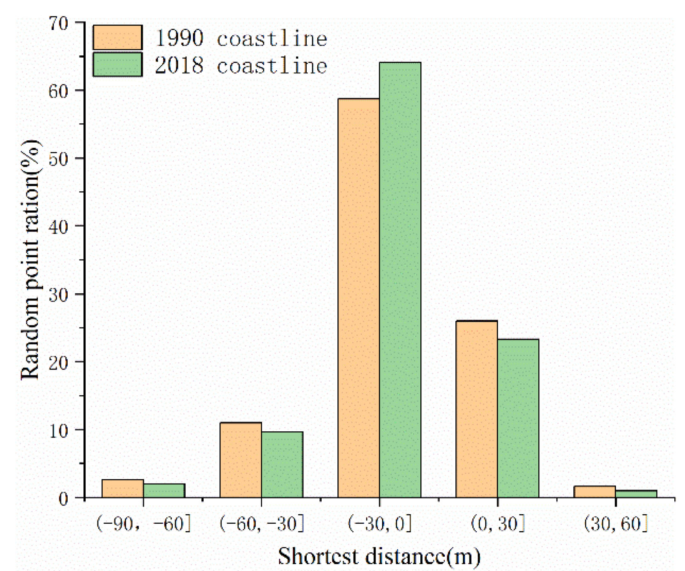

(b)

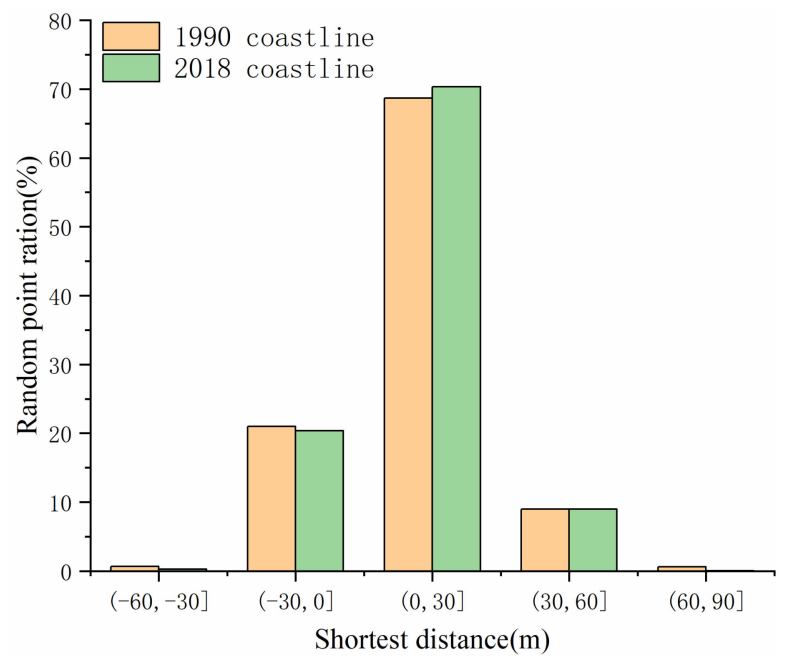

(c)

Figure 5. The accuracy assessment of coastline extraction: (a) Verification area 1 is located near Sumatra; (b) Verification area 2 is located near Java; (c) Verification area 3 is located near Sulawesi. (Note: (a-c) are arranged from west to east).

\subsection{Space-Time Analysis Method for Coastlines}

\subsubsection{Index of Coastline Utilization Degree}

By drawing on the concept and calculation method of land use, the index of coastline utilization degree (ICUD) was determined here [65]. Referring to the definition of the coastline utilization grade index in the study by Wu et al. [65], this article also used the relevant indices. Human activities have a greater impact on the coastline, and the difficulty in restoring the coastline to a natural state has increased, resulting in a decline in the diversity of coastline functions. The index of human force degree ranged from 1 to 4 (Table 3).

The index of coastline utilization degree was calculated through Equation (1):

$$
\operatorname{ICUD}=\sum_{i=1}^{n}\left(A_{i} \times C_{i}\right) \times 100
$$

where ICUD is the index of coastline utilization degree, $A_{i}$ is the impact score of human force degree for category $i$ utilization, $C_{i}$ is the coastline length percentage of category $i$ utilization, and $n$ is the classification number of coastlines. 
Table 3. Indices of human force degree for all utilization situations of coastline.

\begin{tabular}{cccccccc}
\hline Utilization & $\begin{array}{c}\text { Bedrock } \\
\text { Coastline }\end{array}$ & $\begin{array}{c}\text { Silt } \\
\text { Coastline }\end{array}$ & $\begin{array}{c}\text { Mangrove } \\
\text { Coastline }\end{array}$ & $\begin{array}{c}\text { Sandy } \\
\text { Coastline }\end{array}$ & $\begin{array}{c}\text { Harbor } \\
\text { and Wharf }\end{array}$ & Embankment & Agricultural \\
\hline Index & 1 & 2 & 2 & 1 & 4 & 4 & 3 \\
\hline
\end{tabular}

\subsubsection{Changes in Land and Sea Patterns}

The process of coastline expansion or receding to the sea will cause changes in the land and sea pattern of the coastline. Land-to-sea retreat or sea-to-land retreat was referred to as land invasion or transgression. Land-to-sea retreat in space was represented by an increase in land area, while sea-to-land retreat was represented by a decrease in land area (Figure 6). The change in land area reflected the direction and magnitude of change in the coastline. Conversely, changes in the use of the coastline also revealed the main driving factors and processes of land-sea pattern changes.

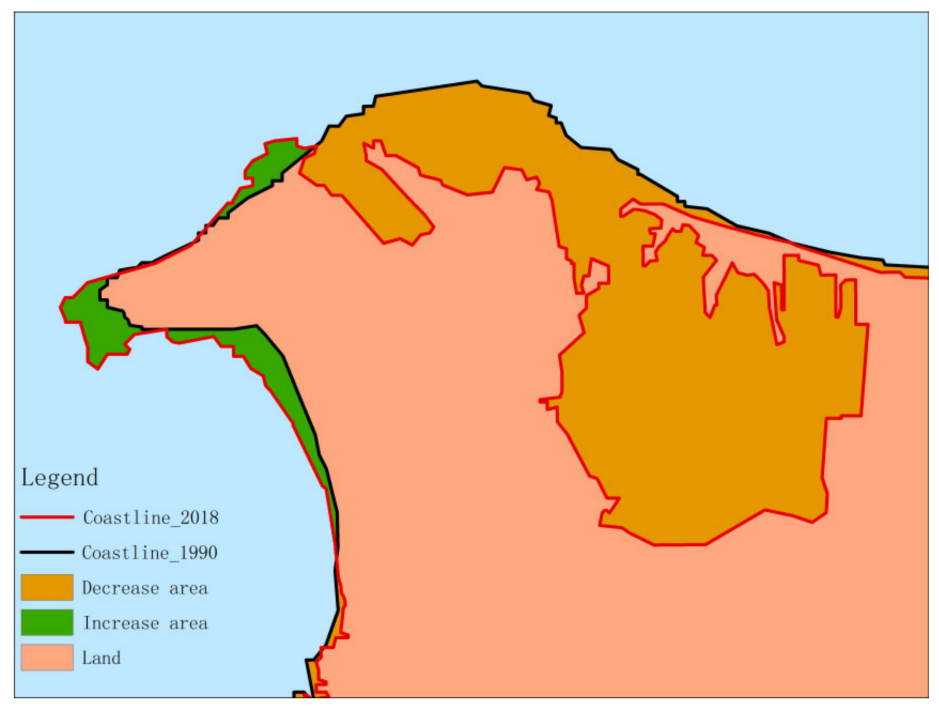

Figure 6. Analysis of changes in land and sea patterns.

The black curve was the position of the coastline at $t_{1}$ in 1990, and the red curve was the position of the coastline at $t_{2}$ in 2018. The two directions were the same, that is, the land was both on the left side of the coastline. The coastlines during the two periods were superimposed, and multiple polygons were generated on both the left and right sides of the earlier coastline. If the later coastline was to the left of the early coastline, it showed that the coastline had receded. On the contrary, if the later coastline was to the right of the early coastline, it showed that the coastline had advanced towards the sea. The formulation that the coastline changes led to land area increasing S (increase) (2) and reducing $S$ (decrease) (3) are as follows:

$$
\begin{gathered}
S_{\text {increase }}=\sum_{i=1}^{j} A_{i} \\
S_{\text {decrease }}=-\sum_{i=1}^{k} B_{i}
\end{gathered}
$$

where $A$ represents the increased area, $j$ represents the number of increased areas, $B$ represents the decreased area, and $k$ represents the number of decreased area. 


\subsubsection{ICUD Analysis at Different Scales}

The ICUD was calculated at the national, island, and provincial scales to analyze the regional differences in Indonesia's coastline resources. The island scale referred to the geographical zone of Indonesia that was divided into seven spatial units: Sumatra, Kalimantan, Java, Sulawesi, Nusa Tenggara, Maluku, and Papua. We also analyzed the differences between these islands. Furthermore, the differences in the degree of coastline between Indonesia's 33 provinces were analyzed and classified. (Table 4).

Table 4. ICUD classification degree.

\begin{tabular}{ccccc}
\hline Degree & I & II & III & IV \\
\hline ICUD & $<150$ & $150-200$ & $200-250$ & $>250$ \\
\hline
\end{tabular}

\section{Results}

\subsection{Spatial Distribution Characteristics of Coastlines and ICUD}

The coastline types in 1990 and 2018 were obtained by acquiring images of the coastal areas of Indonesia covered by remote sensing satellites over the past 28 years, and subsequently interpreting them. The spatial distribution is shown in Figure 7.

According to the statistics of the coastline classification results shown in Figure 7, the total length of Indonesia's coastline in 1990 was $90,586.25 \mathrm{~km}$, of which the total length of natural coastline was $72,895.98 \mathrm{~km}$, the total length of artificial coastline was $17,690.27 \mathrm{~km}$, and the ICUD of coastline was 169.69. The total length of Indonesia's coastline in 2018 was $91,363.65 \mathrm{~km}$, of which the total length of natural coastline was $66,901.46 \mathrm{~km}$, the total length of artificial coastline was $24,462.19 \mathrm{~km}$, and the ICUD of coastline was 186.43 .

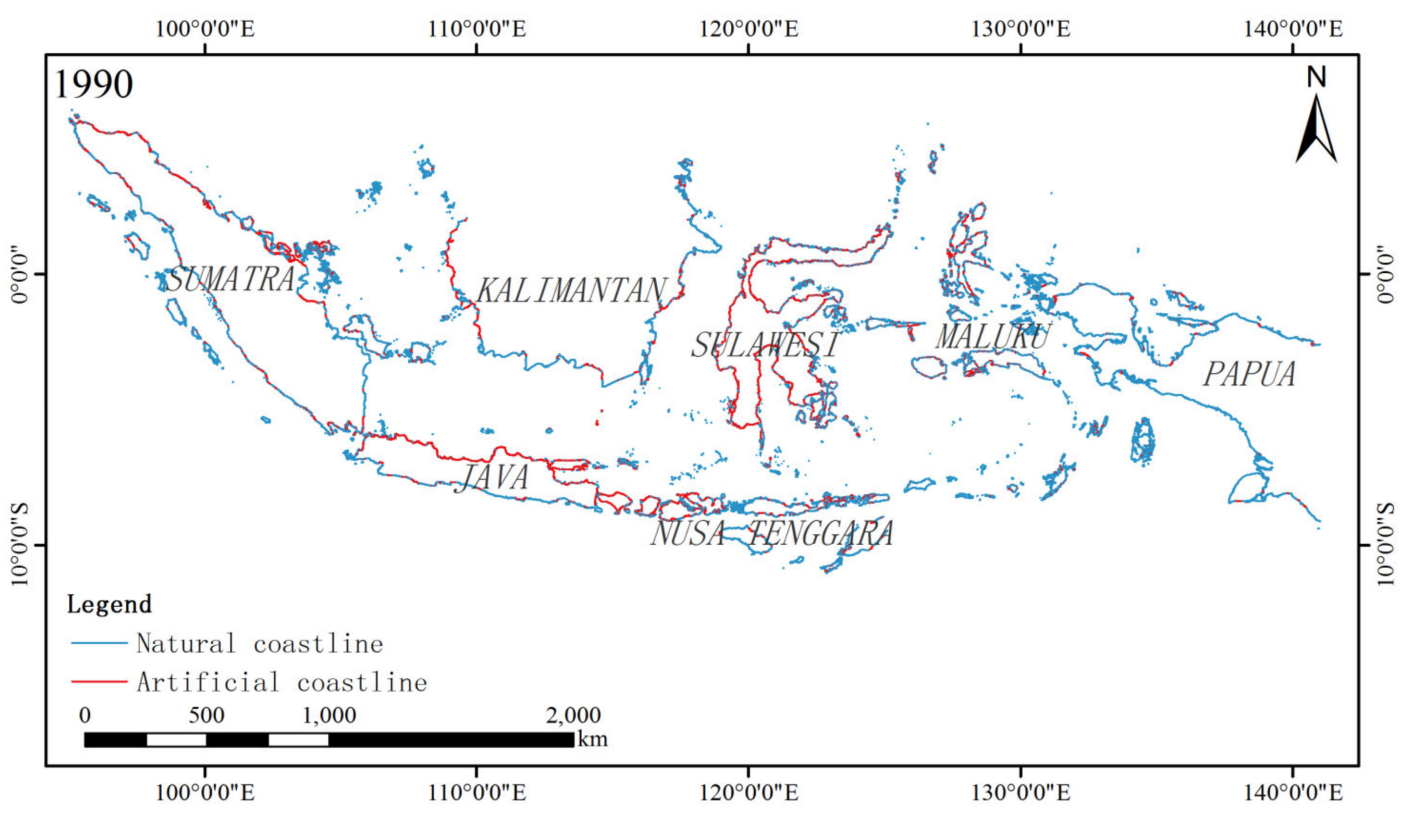

Figure 7. Cont. 


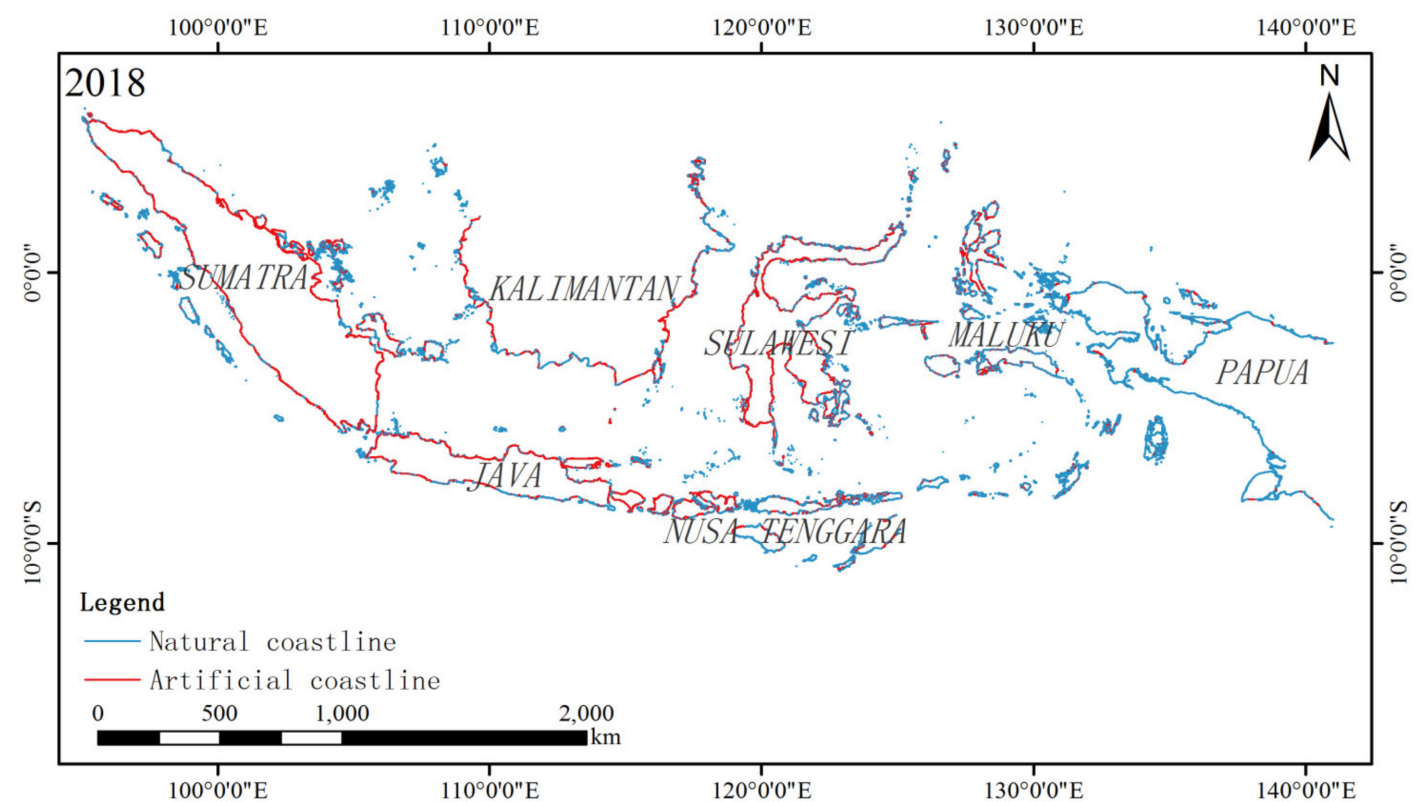

Figure 7. Distribution map of the Indonesian coastline of first types from 1990 to 2018.

The results of the two periods showed that over the past 28 years, due to the comprehensive effects of human development and sea-land interaction, the total length of Indonesia's coastline increased by $777.40 \mathrm{~km}$, of which the natural coastline decreased by $5994.52 \mathrm{~km}$, the artificial coastline increased by $6771.92 \mathrm{~km}$, and the ICUD increased by 16.74 . The areas with the most significant changes in artificial coastlines were located on the south coast of Sumatra and Java, the southeastern coast of Kalimantan, and the northern coast of the Maluku Islands. The results show that over the past 28 years, Indonesia's natural coastline has accounted for more than $70 \%$ of the total coastline, indicating that Indonesia's coastline resources have not changed significantly and their potential for development and utilization remains huge.

In general, different types of coastline resources often have multiple uses. This is shown in the statistics for the lengths of different types of coastlines in the secondary categories (Figure 8); among the natural coastlines, all types of coastlines are decreasing, the most significant decrease of which was the bedrock coastlines. These decreased by $4266.65 \mathrm{~km}$ in $1990-2018$, and its proportion decreased from $53.66 \%$ in 1990 to $48.51 \%$ in 2018 . The reason was that bedrock coastline had advantages in the openness, cover conditions, and water depth of the basin, and could often form an excellent harbor. Under these conditions, it was used for transportation and sea construction, and it had a higher port level and navigation capacity. A reduction of $451.15 \mathrm{~km}$ of silt coastline was observed. The silt coastline was often used for tidal flat farming. The mangrove coastline decreased by $259.68 \mathrm{~km}$. The increase or decrease of the mangrove coastline, to a certain extent, indicated the ecological environment of the region. The reduction of the mangrove coastline should be closely monitored. The sandy coastline was reduced by $997.04 \mathrm{~km}$. Although the sandy coastline has poor conditions for port construction, it is gentle and open and can be used for fisheries and tourism. Among the artificial coastlines, all types of coastlines increased, of which agricultural coastline increased the most, reaching $3678.06 \mathrm{~km}$ and accounting for more than half of the total artificial coastline growth length. Second was embankment coastline, which increased by $2776.27 \mathrm{~km}$ during the last 28 years, and the proportion increased from $10.07 \%$ in 1990 to $13.02 \%$ in 2018 . The harbor and wharf coastline only increased by $227.59 \mathrm{~km}$. However, as the most important transportation building facility for domestic and international traffic flows, the increase in the length of the quay is particularly important for Indonesia's exchanges with other countries. 


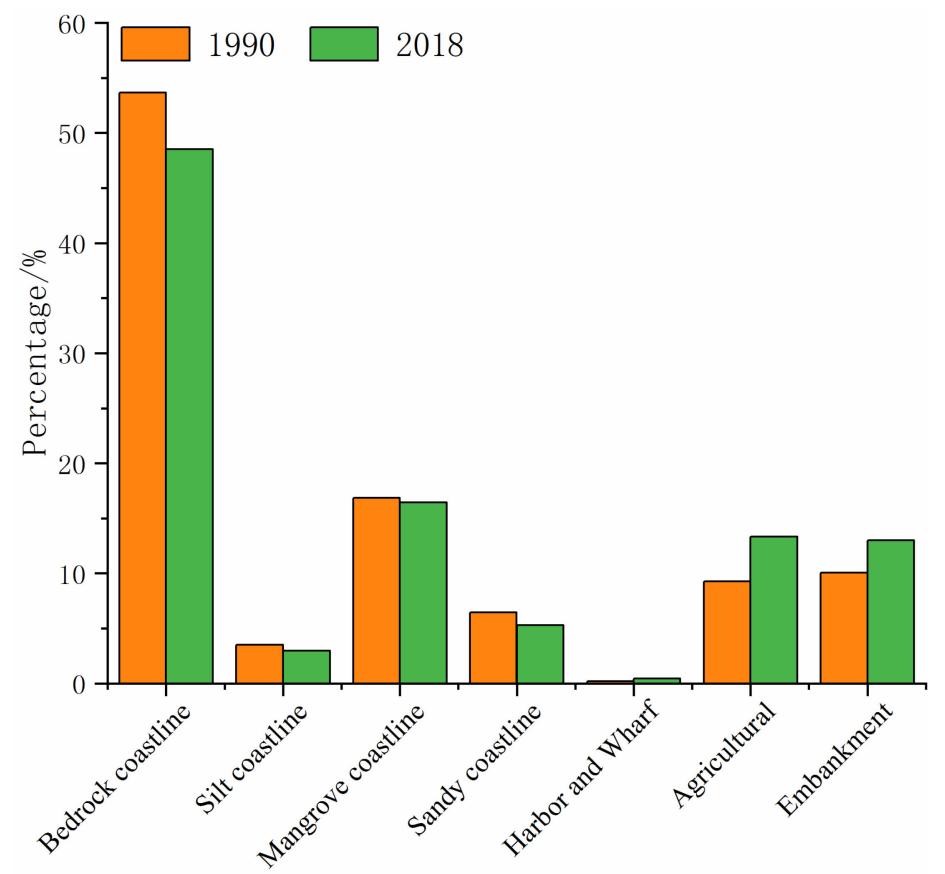

Figure 8. Percentage results of different types of coastline length in 1990 and 2018.

\subsection{Temporal and Spatial Dynamics of ICUD on the Island Scale}

The islands of Indonesia are scattered, including Kalimantan, Sumatra, Nusa Tenggara, Maluku, Papua, Sulawesi, and Java. There are rugged mountains and hills in the interior of the islands. Only the coastal areas have narrow plains that are surrounded by shallow seas and corals. For example, on Kalimantan Island, the mountains stretch from the middle to the west, the coastal plain is vast, and the south is swampy. In Sumatra, the mountains range from northwest to southeast. On the northeast side of the mountains are hills and a wide coastal alluvial plain. The plains are swampy in the east. Sulawesi, mostly mountainous, has narrow plains only along the coast. Java has a plain in the north and a lava plateau and mountains in the south. Therefore, different landforms make Indonesia's coastline resources show obvious regional differences on the island scale.

On the whole (Figure 9), artificial coastlines are dominated by agricultural and embankment dikes, which are mostly distributed on plain coasts that are easy to develop and on economically developed and densely populated estuaries, such as Java Island. Most of the natural coastlines are bedrock coastline, although some are sandy coastlines and mangrove coastlines. The bedrock coastlines are mainly distributed in the south and northeast of Indonesia. Most mangrove coastlines are located at the estuaries, such as in sparsely populated areas in Papua.

It can be seen from the classification result that the ICUD of coastline in 1990 ranked from high to low was: Java Island $>$ Sulawesi $>$ Kalimantan Island $>$ Nusa Tenggara Islands $>$ Sumatra Island > Maruku Islands > Papua Island (Figure 10a). The ICUD in 2018 ranked from high to low was: Java Island $>$ Kalimantan Island $>$ Sulawesi $>$ Sumatra Island $>$ Nusa Tenggara Islands $>$ Maluku Islands $>$ Papua Island (Figure 10b). Moreover, since 1990, the ICUD of Sumatra, Java, Nusa Tenggara, Kalimantan, Sulawesi, and Maluku has increased. However, the ICUD of Papua Island has remained stable. 

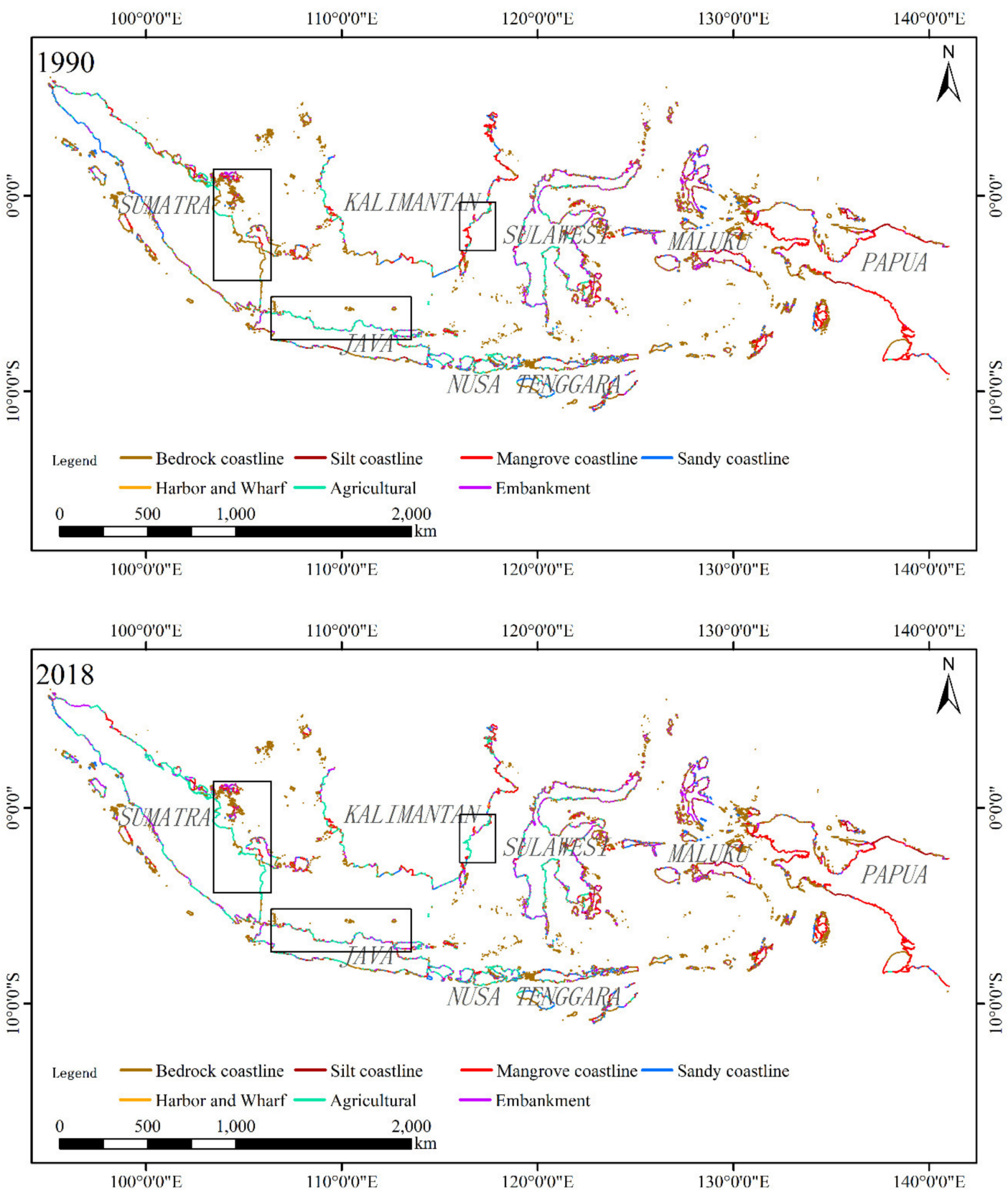

Figure 9. Spatial distribution of secondary coastlines on the island scale (Note: the significant changes in the two periods are marked by the black boxes in the figure).

Except for the proportion of bedrock coastlines in Nusa Tenggara and Papua, the proportion of bedrock coastlines for the other islands decreased. Apart from the increase in the proportion of silt coastlines on Papua Island, the proportion on the other islands decreased. The proportion of mangrove coastlines in Sumatra, Java, and Nusa Tenggara Islands rose, and it declined for the rest of the islands. The proportion of mangrove coastlines in Kalimantan fell the most, from $40.86 \%$ in 1990 to $12.06 \%$ in 2018 , and a reduction of $669.11 \mathrm{~km}$ in length was obtained. The proportion of sandy coastlines declined, except for on Papua Island. Except for the decline in the proportion of the agricultural embankment on Java Island, the proportion rose for all of the rest of the islands. The increase in the agricultural dikes in Sumatra was the largest, increasing by $5.33 \%$ in the past 28 years. The proportion of harbor and wharf, and embankment lines rose on all islands. The largest increase in the proportion of wharves was on Java, and the largest increase in embankment was on Kalimantan. The length of the construction dikes has increased by $415.06 \mathrm{~km}$ during the past 28 years. 


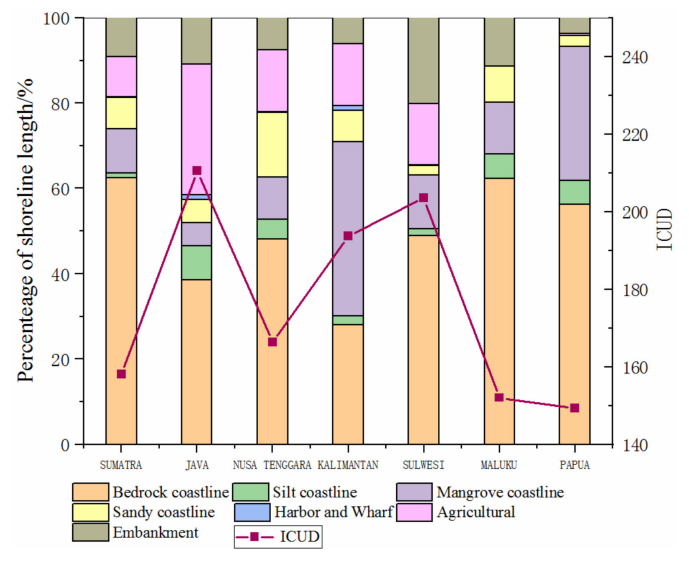

(a)

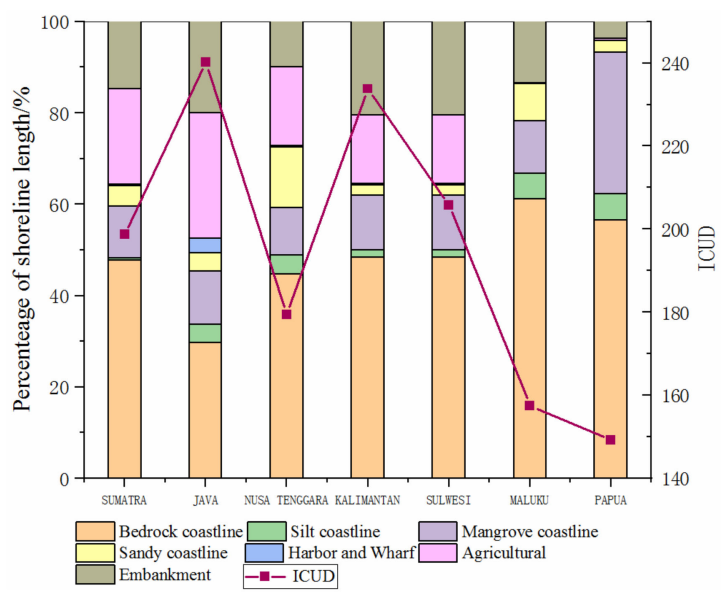

(b)

Figure 10. ICUD time variation on the island scale: (a) 1990 (b) 2018.

\subsection{Temporal and Spatial Dynamics of ICUD Degree at the Provincial Scale}

As seen above, the island differences in Indonesia's coastline were analyzed on the scale of different islands. The regional differences between different provinces will now be discussed from the perspective of the provincial scale.

The provinces with the highest coastline development and utilization (ICUD > 250) in 1990 were Sulawesi Barat and Bali, and the provinces with the highest ICUD in 2018 were Sulawesi Barat, Bali, Riau, Sumatera Selatan, Jawa Tengah, and Jawa Barat (Figure 11). In the two phases, both Sulawesi Barat and Bali were the provinces with the highest coastline development and utilization. However, Sulawesi Barat's coastline development and utilization remained around 295 during 1990-2018. The development and utilization of Bali's coastline increased from 255.18 in 1990 to 277.08 in 2018. The provinces whose value of development and utilization of coastline changed by more than 50 in the two phases were counted, and include Bangka-Belitung, Banten, Bengkulu, Kalimantan Selatan, Lampung, Riau, Sumatera Selatan, and Sumatera Utara. The largest change was in Sumatera Selatan province, from 100 to 266.43 in 1990-2018; the province's coastline development and utilization increased by 166.43 .

The areas with large changes in the level of coastline development and utilization from 1990 to 2018 were mainly located in the western region of Indonesia, of which the coastline development and utilization on the Sumatra, Java, and Kalimantan islands had larger changes (Figure 12). However, the eastern regions of Nusa Tenggara, Sulawesi, Maluku, and Papua remained unchanged. The results are inseparable from the tendency of "emphasizing the west and neglecting the east" in successive governments after colonial independence [66]. Although Indonesia's western region is closer to Malaysia and Singapore, with frequent trade exchanges and population migration, natural resources such as agricultural, fishery, and mineral deposits are extremely rich in the eastern region of Indonesia. Its geographical location is close to the Philippines and Australia, and its development potential cannot be underestimated. In 1990, only two provinces with Grade IV coastline development were Sulawesi Barat and Bali. In 2018, four provinces, including Jawa Barat, Jawa Tengah, Riau, and Sumatera Selatan, were added. Among them, the development and utilization of the coastline in Sumatera Selatan Province increased the fastest, jumping from Grade I in 1990 to Grade IV in 2018. 


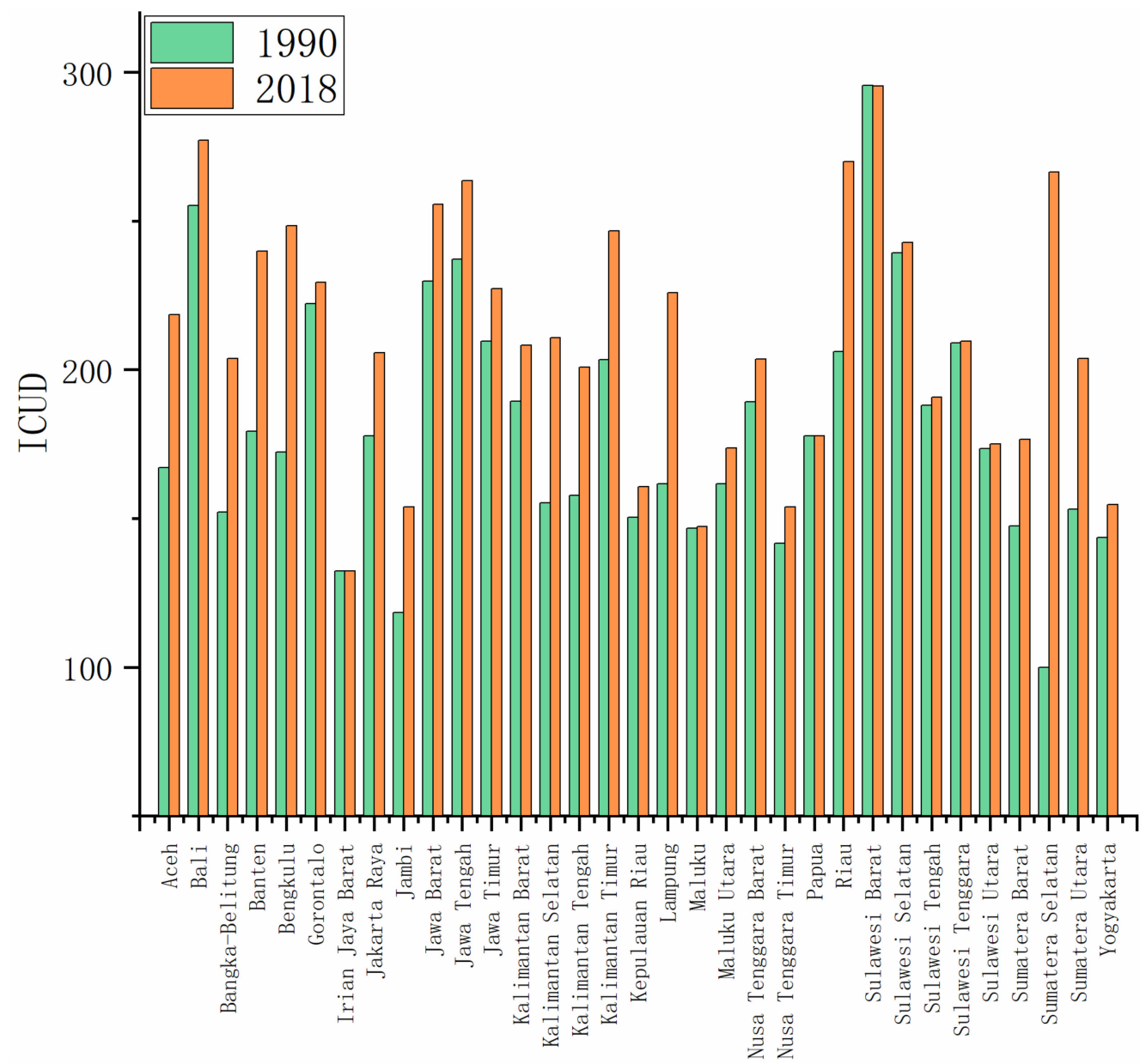

Figure 11. ICUD time variation at the provincial level.

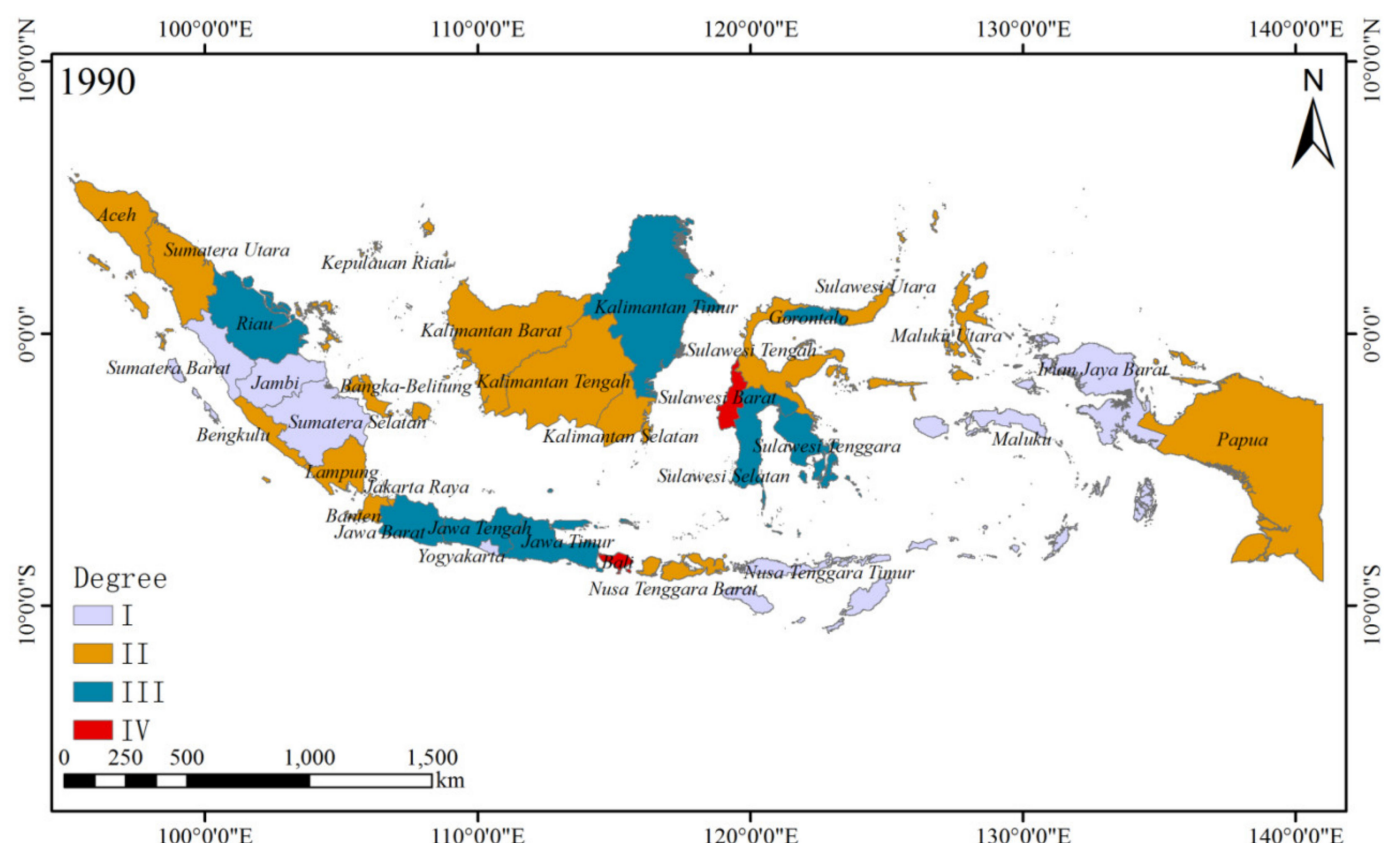

Figure 12. Cont. 


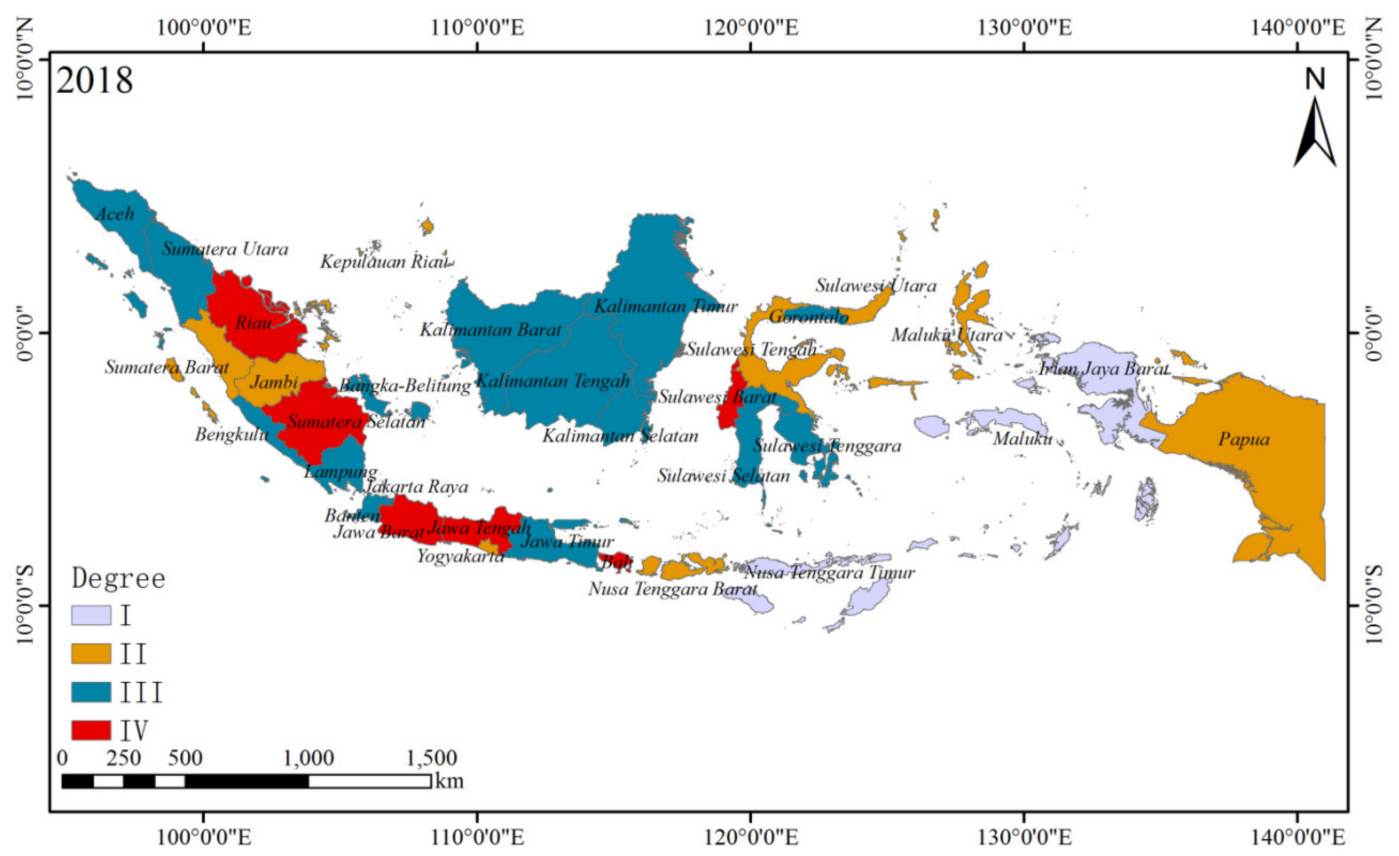

Figure 12. Distribution of ICUD at different degrees on the provincial scale from 1990 to 2018.

\subsection{Spatiotemporal Changes in the Land-Sea Pattern}

We examined the changes in the land area of various provinces and regions in the country from 1990 to 2018, and further analyzed the spatiotemporal changes of the land and sea pattern of the Indonesian coastline over the past 28 years. During this period, the area of Indonesia's landward erosion was $388.09 \mathrm{~km}^{2}$, and the area of seaward expansion was $770.14 \mathrm{~km}^{2}$. These results show that the trend of Indonesia's coastline change was mainly expansion into the sea, and there was less erosion to land.

These results are shown (Figure 13). Erosion and reclamation were distributed in 33 coastal provinces. Among them, the expansion of the land area in Riau Province was the most significant, about $177.73 \mathrm{~km}^{2}$, accounting for $23.08 \%$ of the total land area of the country. Riau Province's largest land expansion area could be related to the Indonesian government's opening of an oil palm downstream industrial zone in Riau Province. Riau Province's economy, based on agriculture and oil chemistry, is expected to strengthen the competitiveness of the national economy. Jawa Timur, Jawa Barat, Sumatera Selatan, and Sumatera Utara had lower land expansion areas (in order). The total expansion area of the four provinces accounts for $31.76 \%$ of the total expansion area of the country. The expansion of seawater erosion in Jawa Barat Province was the most significant, about $54.17 \mathrm{~km}^{2}$, accounting for $13.96 \%$ of the total land receding into the country. According to the remote sensing images, seawater erosion mainly occurred at the junction of the Jawa Barat and Yogyakarta provinces, and the main manifestation was the destruction of agricultural dikes, leading to a reduction in land area (Figure 14a). The land expansion in this area was mainly manifested by the seaward expansion of agriculture (Figure 14b) and the increase of coastal embankments (Figure 14c). The land receding area was lower in the Jawa Tengah, Riau, Kalimantan Timur, Aceh, Sumatera Utara, Kalimantan Barat provinces in sequence. 


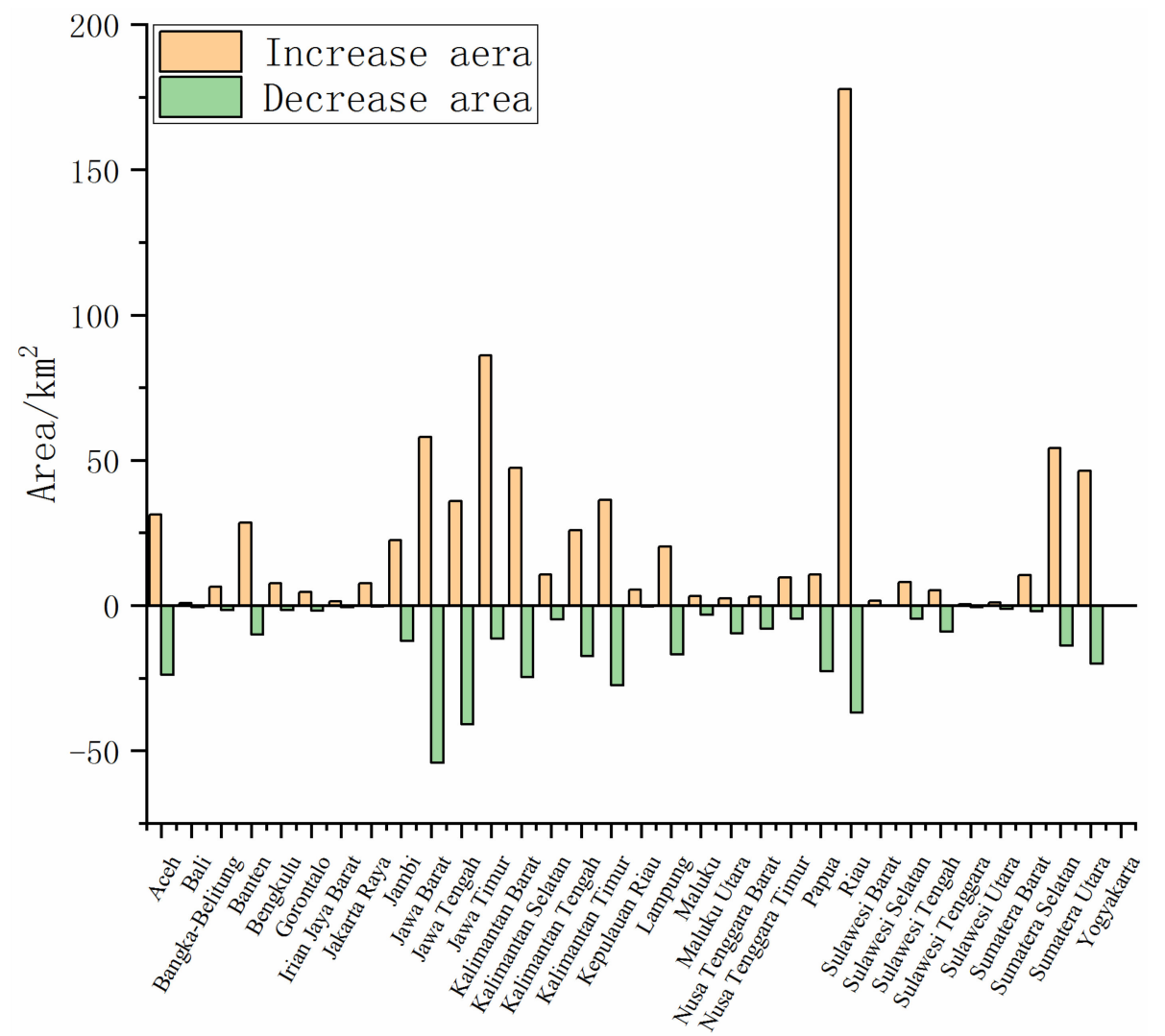

Figure 13. Changes in coastal land and sea patterns in Indonesian provinces.
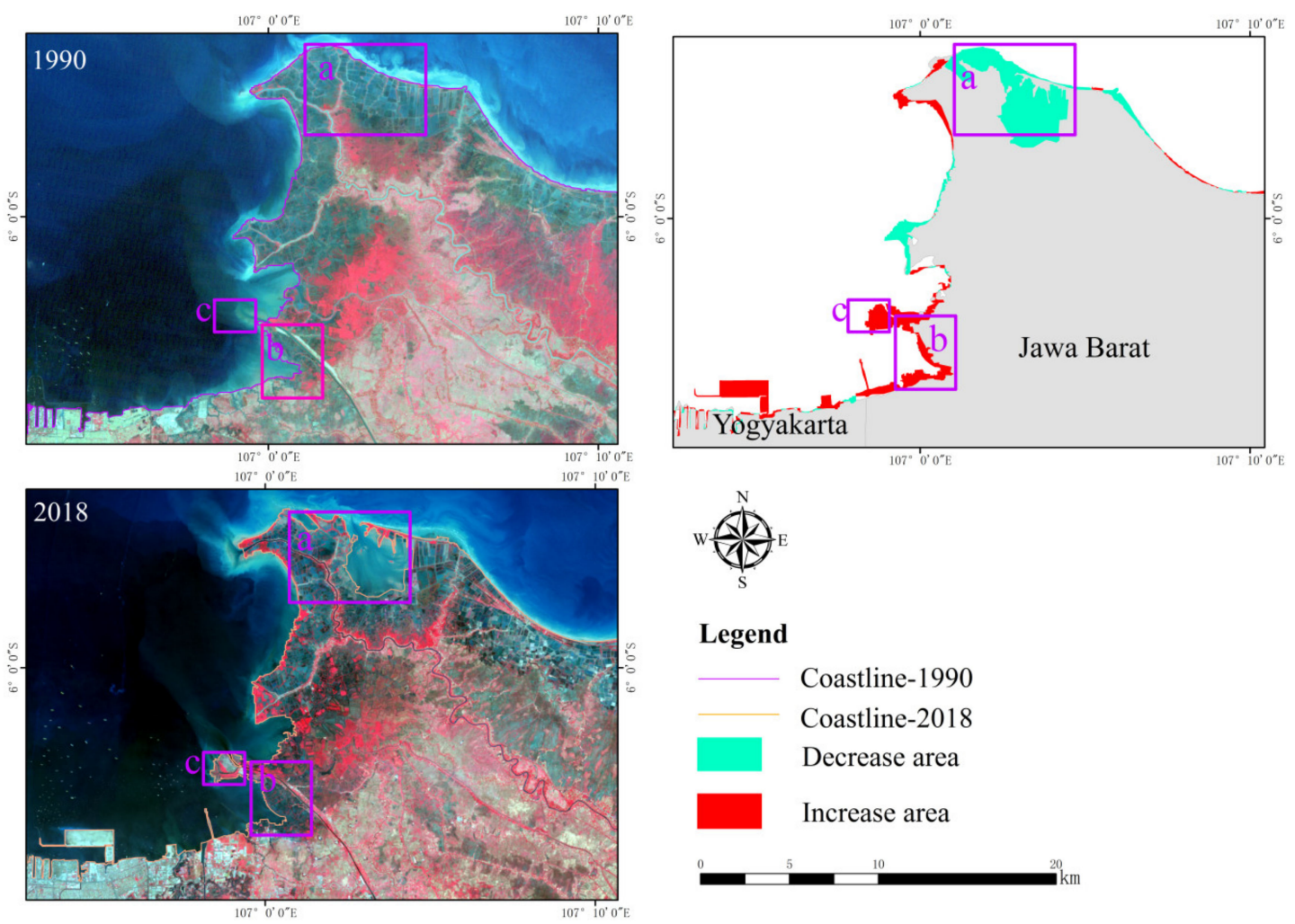

Figure 14. Decrease and increase area changes in Jawa Barat Province, Indonesia. (a) Reduction in land area due to the destruction of agricultural dikes (b) Land expansion due to the seaward expansion of agriculture (c) Land expansion due to the construction of coastal embankments (Note: the change area unit is $\mathrm{km}^{2}$ ). 
In order to make it easier for us to see the overall changes in the land and sea pattern of the Indonesian region, the values of the increase and decrease area are displayed in space on a scale of $10 \mathrm{~km}^{2}$ (Figure 15). From the spatial distribution, Sulawesi, Nusa Tenggara, and Papua had less coastal development and seawater erosion and have remained stable. The seaward expansion of Kalimantan Island was at a medium level, while the seaward expansion of Sumatra and Java was significant, which partly reflects that the human activities of these two islands are the most intense. Among them, both Java Barat and Jawa Tengah provinces on the island of Java showed a significant state of land expansion and seawater erosion, which requires close attention.

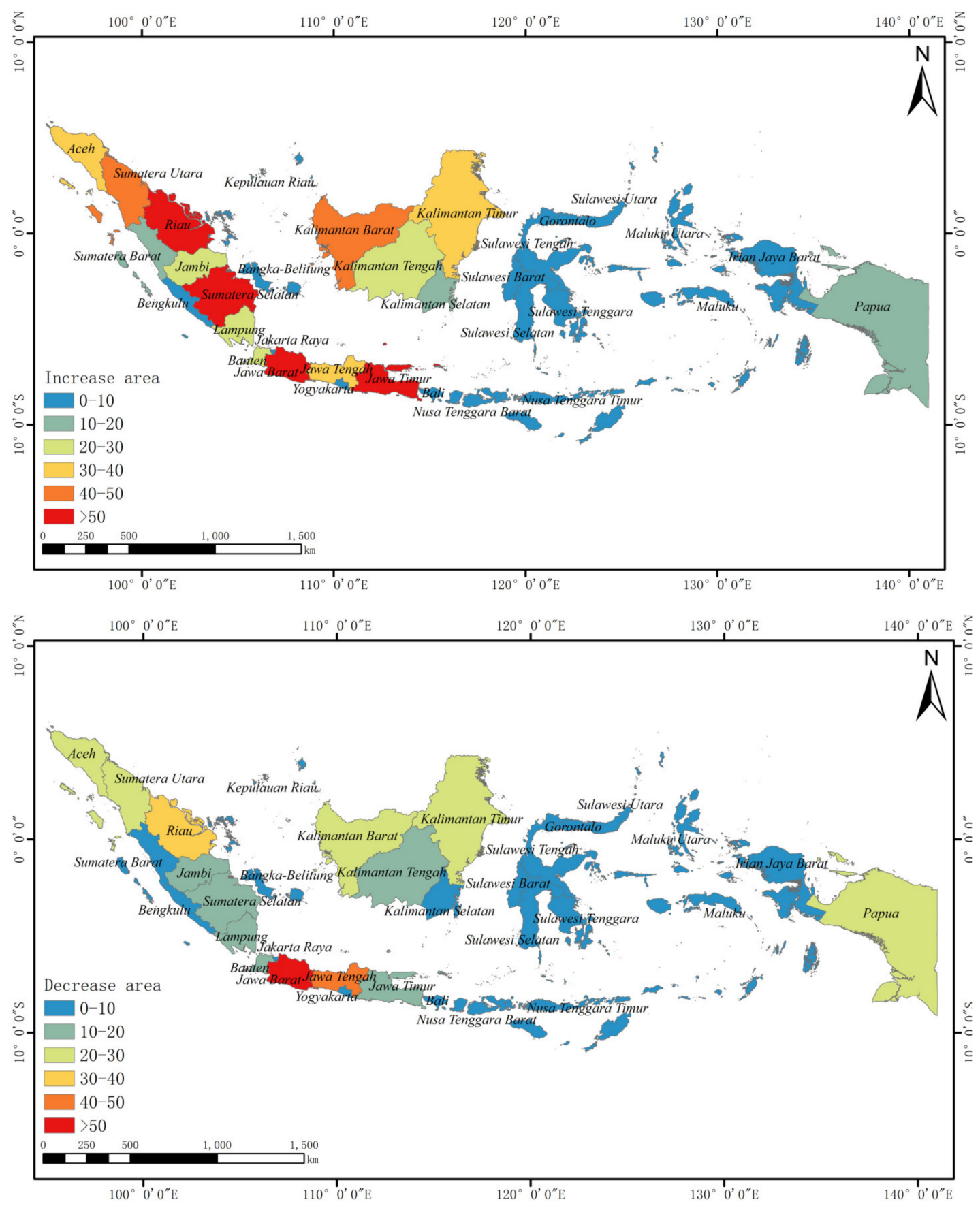

Figure 15. Spatial distribution map of increase and decrease area in Indonesia's provinces (Note: The change area unit is $\mathrm{km}^{2}$ ). 


\section{Discussion}

\subsection{Natural Factors of Coastline Change}

\subsubsection{Impact of Climate Change on Coastline Changes}

Climate change is an inevitable natural phenomenon. Due to their proximity to the ocean, the coastal regions of the world are being affected by severe natural disasters caused by global warming, such as sea water intrusion, coastline erosion, and waterlogging [67]. Statistics pertaining to coastline change provide a better understanding and measure of the direct response to sea level rise $[68,69]$. In low-lying areas, especially Southeast Asian countries, a large number of people live in low-lying and fragile coastal plains and are considered to be at greater risk of being affected by the climate [70]. The Indonesian region is a country severely affected by both natural disasters and climate change.

On the one hand, the tsunami is the most direct and active dynamic factor in shaping the coast. It has a significant impact on coastal buildings, such as the collapse of dams. At the same time, relative sea level rise caused by global warming has been accelerating, which will have a serious impact on coastal erosion [71-74]. The strong erosion effects of natural disasters such as tsunamis and storms are particularly evident in Banda Aceh on the northern coast of Sumatra. Banda Aceh was the main city receiving the most damage and highest death toll in the 2004 tsunami. This was the most intense tsunami on record, causing about $400 \mathrm{~m}$ of erosion and more than $1 \mathrm{~km}$ of permanent land loss [75]. In addition, the rise of relative sea level is a natural factor causing the erosion of the coastline that also posed a great threat to coastline security. For example, in Semarang (Figure 16), the settlement rate is as high as $10 \mathrm{~cm}$ per year, which is mainly caused by a large amount of groundwater mining, and sea erosion has closed down about $1.5 \mathrm{~km}$ of cities [76]. Therefore, it is of great significance to carry out remote sensing monitoring of the Indonesian coastline to discover the eroded and expanded areas for post-disaster reconstruction. This enables the reasonable allocation of aid and resources according to the spatial distribution of climate change impacts.
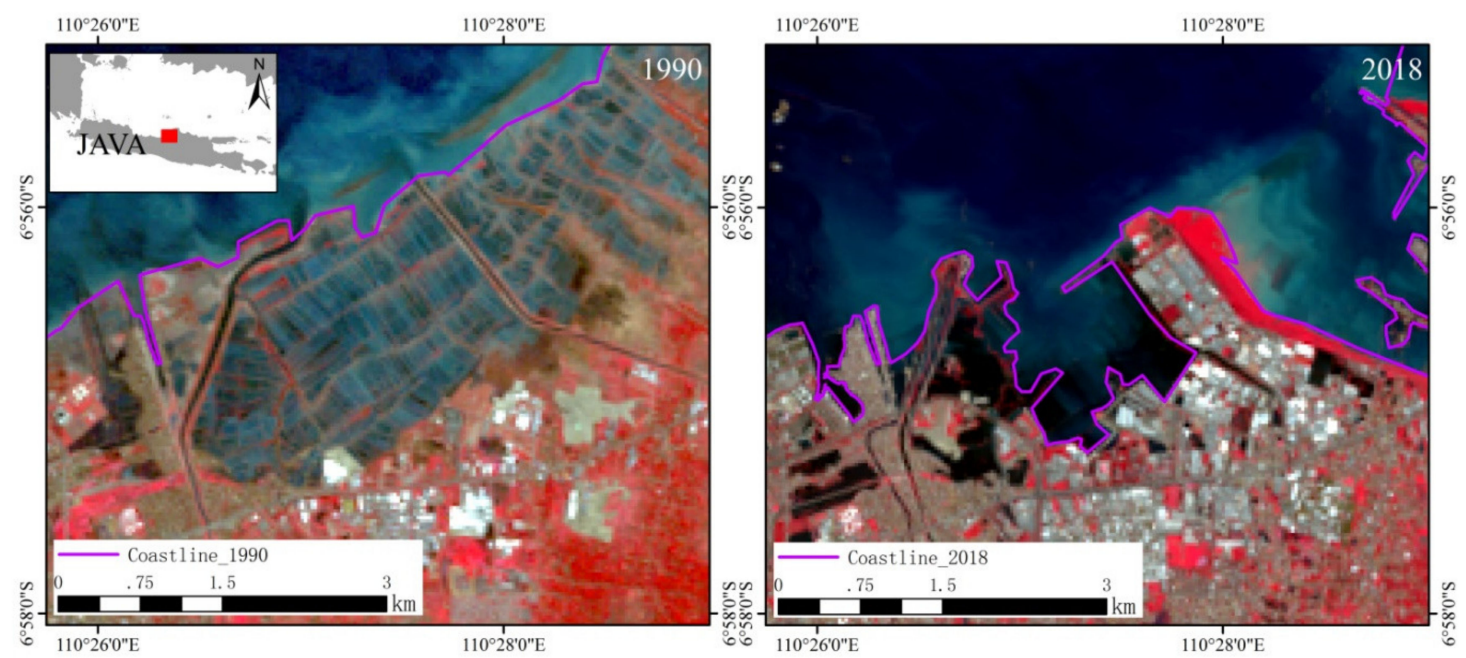

Figure 16. Semarang city and nearby coastline area in 1990 and 2018.

\subsubsection{Geographical Environment's Influence on Coastline Changes}

The particularity of the geographical environment to which the coast belongs also makes changes to the coastline present a certain regular distribution. For example, during 1990-2018, the areas where the secondary type of coastline changed significantly were mainly located in the eastern part of Sumatra and the northern part of Java (refer to Section 4.2), while the western part of Sumatra and the southern part of Java changed little. This is because the hard rock coasts are mainly in the western and southern 
regions, and it is difficult for this special geographical environment to be transformed into other types of coasts.

In addition, bays and estuary tidal flats often have high ecological and economic value and are the first choices for human migration. As a result, the areas change frequently and the environment is destroyed. For example, changes in the coastline of mangroves, and tidal flats in bays and estuaries often form a calm, hidden mangrove coastal environment, which is conducive to the rapid accumulation of fine particulate matter. However, for nearly 28 years, Indonesia's mangrove coastline has been in decline. Statistics showed that Indonesia has lost 40 percent of its mangrove forests, mainly due to aquaculture occupation of mangrove areas, which is also consistent with the increasing trend of agricultural coastline in these statistics. The reduction of mangroves in Indonesia will have a serious impact on global climate change [77]. Therefore, it is necessary to pay close attention to the development trend of the mangrove coastline in Indonesia.

\subsection{Social Factors of Coastline Change}

The construction of maritime infrastructure is a prerequisite for the interconnection of major islands in Indonesia, including maritime highways, deep sea ports, shipping, and marine tourism. The proportion of quay walls in Indonesia reached only $0.43 \%$ in 2018. According to World Bank statistics, Indonesia's population ranks fourth in the world, after China, India, and the United States. However, its population distribution is very uneven. The 32 provinces of the country are divided into two regions, east and west. The west includes 17 provinces, and $78 \%$ of the country's 217 million people live in the west. The eastern part contains 15 provinces, covering $70 \%$ of the country's area but only $22 \%$ of the country's population [66]. This is also the main reason for the differences in the development and utilization of the eastern and western coastlines, and previous governments tend to "more emphasize the development of the west".

Indonesia's GDP has increased from US \$ 10.614 billion in 1990 to US \$ 104.217 billion in 2018. Indeed, GDP has increased by more than 9 times in the past 28 years. However, the development and utilization index of the coastline has increased by only 16.74 during this period, indicating that the growth of GDP has a small impact on the development and utilization of the coastline (Figure 17). Indonesia's population increased by about 1.5 times during the period 1990-2018. During this period, the growth rate of agricultural coastlines was twice as fast as that of artificial coastlines, indicating that the growth of Indonesia's population is the leading factor behind changes in agricultural coastlines.

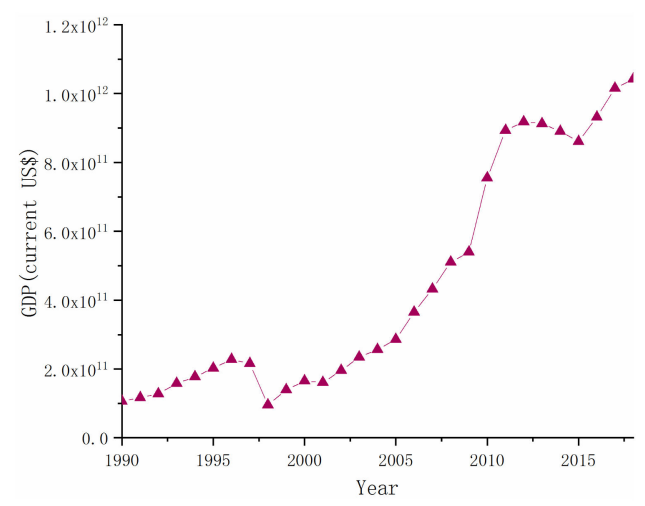

(a)

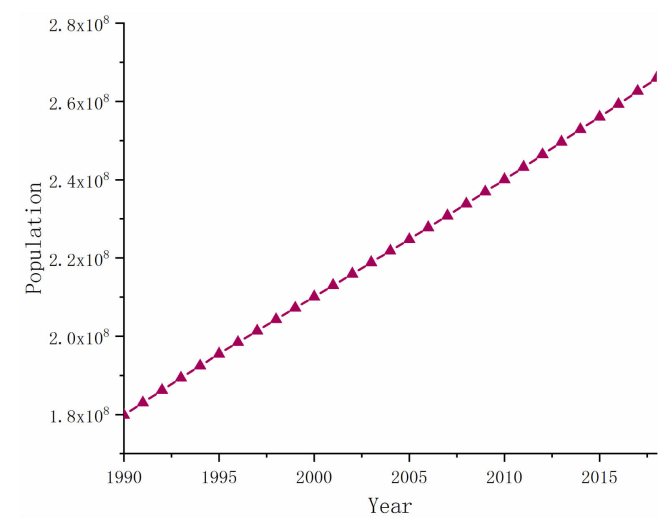

(b)

Figure 17. Indonesian GDP and demographics, 1990-2018 (Data source: https://data.worldbank.org.cn/). (a) Growth Trend of Indonesian GDP, 1990-2018. (b) Growth trend of Indonesian population, 1990-2018.

According to the overlay analysis of the population data and coastline development and utilization index of different provinces from 1990 to 2018 (Figure 18): 
(1) Jawa Barat, Jawa Timur, and Jawa Tengah provinces were the top three provinces in Indonesia in terms of population distribution over the years, but the region's coastline development and utilization were not the highest. For the third-ranked Jawa Tengah, the coastline ICUD was higher than the top two of Jawa Barat and Jawa Timur provinces. The population of Sulawesi Barat province in 2018 was only 1,405,000, but the coastline development and utilization index of 295.29 in the province was the highest over the years. The second was Bali province, with a population of 4,380,800 and a coastline development and utilization index of 277.08 in 2018. The above phenomenon indicated that the provinces with the largest populations did not have high ICUD, while the relatively small populations of the Sulawesi Barat and Bali provinces had higher ICUD. This shows that the degree of ICUD in Indonesia is mainly related to the low-lying flat areas for human habitation along the coast. And the habitability of coastal geographical conditions is more important than the number of populations in determining the ICUD of the coastline.

(2) Over time, the province with the largest population increase was Jawa Barat, but the ICUD in the region only increased by 26.01. The population in the Irian Jaya Barat and Sulawesi Barat provinces increased by 821,378 and 846,349 , respectively. However, the ICUD of these two provinces showed a downward trend. Irian Jaya Barat is located in the northwest of Papua. Most of the mountains and plateaus are above $4000 \mathrm{~m}$ in altitude. It is the highest island in the world. It can be seen that the difficulties caused by natural topography are the biggest reason for the poor development of the province and city. Sulawesi Barat province, whose economy relies mainly on mining, agriculture, and fishing, is in western Sulawesi. Since the central part of the province is dominated by mountainous terrain and only has low elevations in coastal areas, the population, economy, and agriculture of this region are mostly distributed in coastal areas. As seen in Section 4.3, the province and city had a large ICUD in 1990. With the increase in population, the general phenomenon that the ICUD in the region decreased instead of rose indicates that the region's coastline development had reached the maximum.

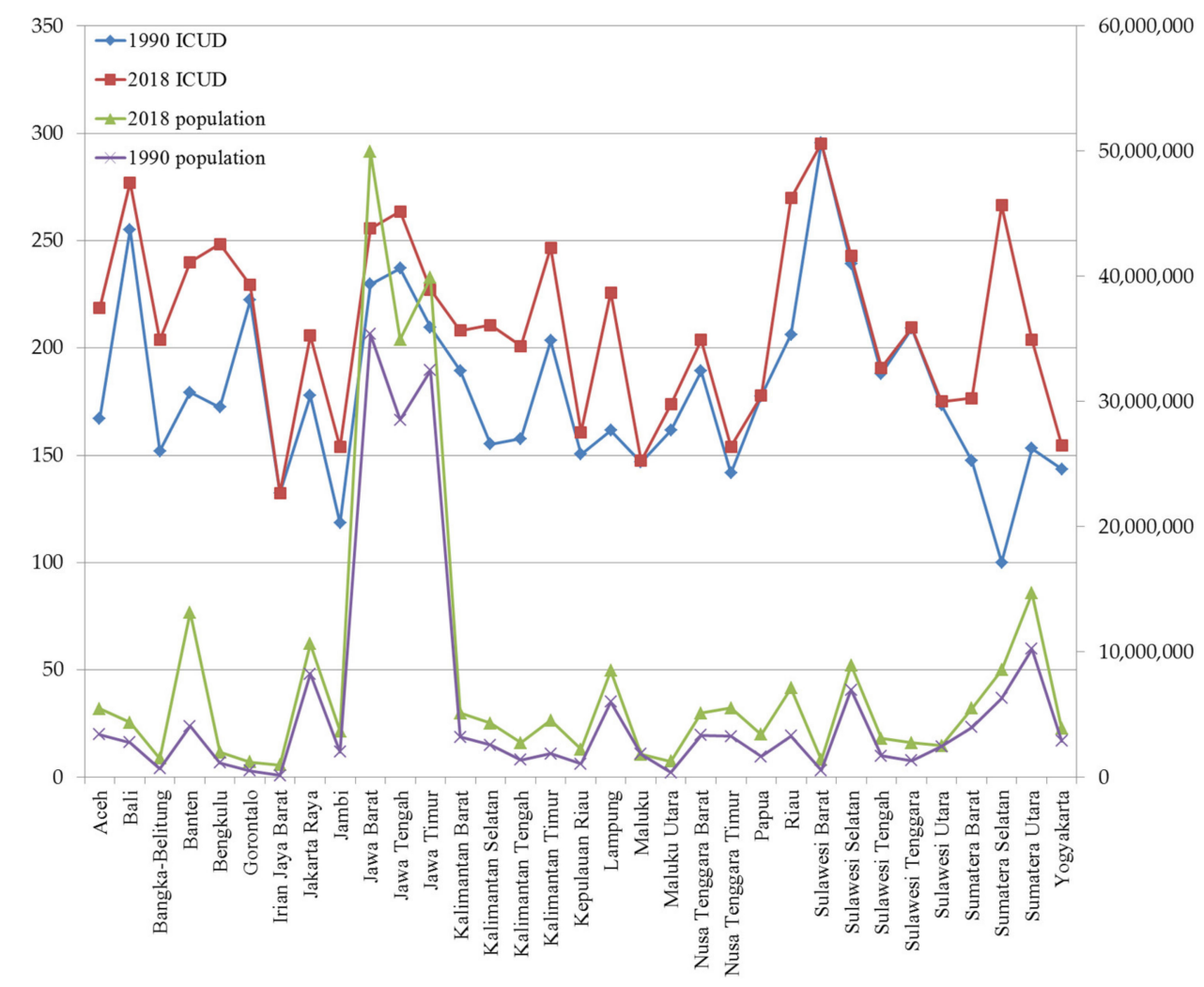

Figure 18. Overlay analysis of coastline development utilization and population data in Indonesian provinces (Data source: https://www.bps.go.id/). 


\subsection{Advantages and Disadvantages of Monitoring Coastline Change by Remote Sensing}

Using remote sensing technology based on open source remote sensing satellite data, the method of the dynamic monitoring of coastline resources has the advantages of low cost, a historical archive, and wide coverage [78,79]. Moreover, the extraction results are highly relevant to the integrated and sustainable management of coastal areas, such as planning, decision-making, management, and monitoring [80-82]. In order to identify trends in coastline types, long-term observations of the ocean need to be achieved through time series assessments. In view of this, we made full use of the potential of remote sensing technology for dynamic monitoring and used open source satellite images of land resources with a long time series coverage to evaluate the spatial and temporal distribution of coastlines. In the field survey, we focused on the coastline of Belawan Pier in Medan, Sumatra (Figure 19a), and the mangrove coastline along the coast of Samadalin, Kalimantan (Figure 19b). The findings were consistent with the types of results extracted in this paper, which also illustrated the reliability of dynamic monitoring using remote sensing technology.

However, there are also several deficiencies. In performing coastline classification, interpreters need to have rich prior knowledge, and the classification accuracy is limited by the resolution of remote sensing images. At this stage, there are still some difficulties in the automatic extraction and classification of large areas, mainly relying on visual interpretation. Therefore, in the future, developing remote sensing technology for the automatic extraction and classification of coastlines can be considered to improve work efficiency. At the same time, the remote sensing data and methods used in this paper have certain limitations concerning the impact of ocean currents on the coast and the damage to coastal ecosystems. Further, some geological problems, such as the impact of new structures on coastal subsidence, require further data and technical means for further study.
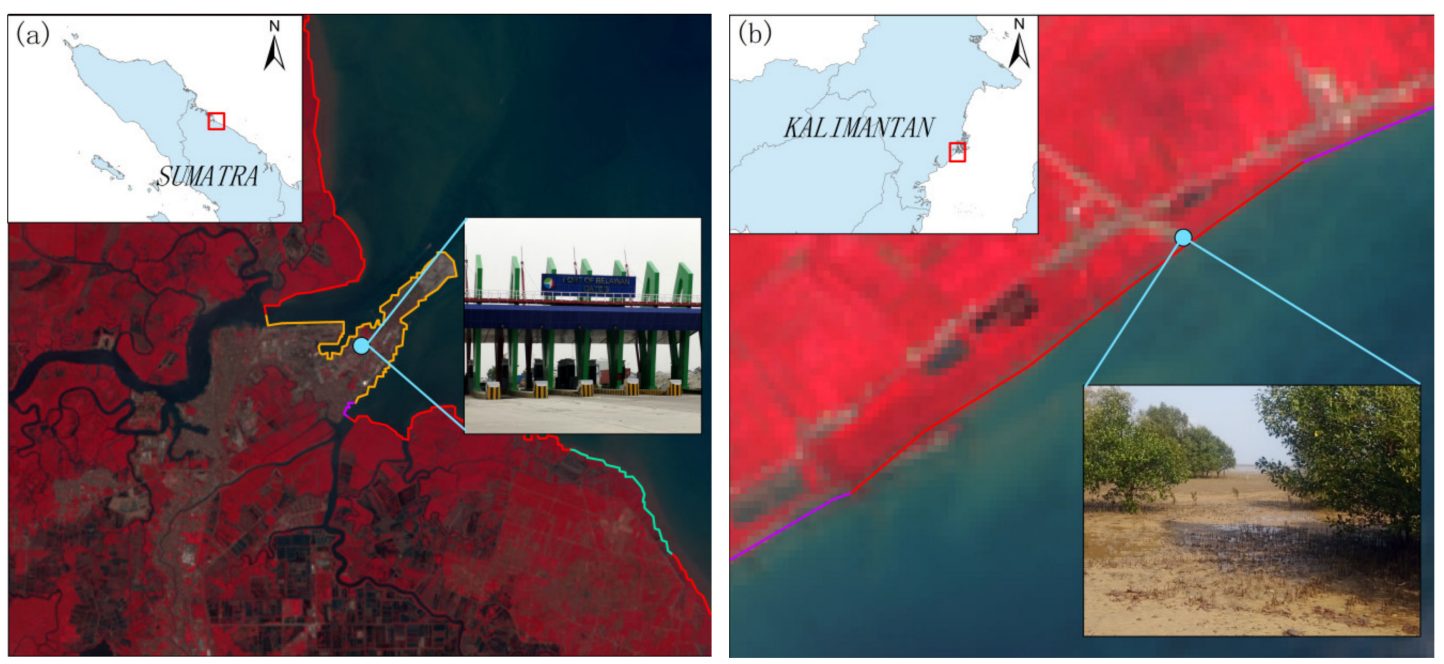

Figure 19. On-the-spot investigation. (a) Sumatra (b) Kalimantan.

\section{Conclusions}

The following conclusions were obtained through long-term remote sensing monitoring of Indonesia's coastline:

(1) The overall trend of Indonesia's coastline changes in the past 28 years was the increase in the total length of the coastline, including a decrease in natural coastline, an increase in artificial coastline, and few changes in the overall type of the secondary types. In 1990, artificial coastlines in Indonesia were mainly distributed on the north coast of Sumatra and Java, the west coast of Kalimantan, and Sulawesi. In 2018, the artificial coastline coverage of the entire Sumatra Island was $90 \%$, and Java Island was also fully developed. The change in land-sea pattern was mainly land-to-sea retreat, of which $770.14 \mathrm{~km}^{2}$ has expanded to the sea in the past 28 years. The land 
expansion in Riau Province was the most serious, and the seawater erosion in Jawa Barat Province was the most serious.

(2) The main constraint factor that causes the dynamic change of Indonesia's coastline is the terrain, which causes Indonesia's population and industry to be mostly distributed in the coastal plains. The result also confirm that in different provinces a larger the population does not correspond to a higher ICUD. The main driving factor is the increase in population, which has led to the intensification of human activities related to coastal engineering, including the construction of port terminals and the reclamation of agricultural facilities. However, the intensification of human activities has also led to the degradation of mangrove ecological coastlines, which will have a certain impact on the coastal ecological environment.

(3) The use of remote sensing technology can quickly monitor the history and current status of long-term serial coastlines in large regions and provide objective data for rational coastal planning. This article takes the dynamic changes in the coastline of Indonesia as a research object and shows the great potential of remote sensing monitoring. In the future, we will use the advantages of the high frequency and wide range of remote sensing to carry out larger-scale and more detailed research on coastline remote sensing monitoring applications, in order to provide effective technical support for coastal area planning and management.

This study provides basic data on the spatial dynamics of island coastline changes at different scales. The conclusions can provide beneficial help for multi-island countries responding to the effects of climate change and economic development. The spatial dynamics of coastline changes provided by this study are important for coastal managers and planners to prioritize actions related to disaster risk reduction. By understanding areas that are likely to be affected by coastline changes, local governments can modify land use plans and keep coastal residents and economic activities away from dangerous areas. In addition, in heavily eroded areas, the government can implement countermeasures, such as building flood prevention facilities and planting mangroves, to stabilize the coastline. If this data is further combined with socio-economic indicators and physical indicators, the coastline ecosystem can be more accurately described at the micro level. This will become the focus of our future work.

Author Contributions: Conceptualization, Z.W. and X.Y.; methodology, Z.W., X.Y. and J.W.; software, J.W.; validation, Z.W. and L.S.; formal analysis, J.W.; investigation, J.W and L.S.; resources, J.W. and X.Y.; data curation, J.W.; writing —original draft preparation, J.W. and L.S.; writing—review and editing, J.W., Z.W., and L.S.; supervision, L.S and X.Y.; project administration, X.Y.; funding acquisition, X.Y. All authors have read and agreed to the published version of the manuscript.

Funding: This research was funded by the Chinese Academy of Sciences Earth Big Data Science Project of China (Grant No. XDA19060303); the National Science Foundation of China (Grant Nos. 41671436 and 41421001); the Innovation Project of Laboratory of Resources and Environmental Information System (Grant No. O88RAA01YA).

Conflicts of Interest: The authors declare no conflict of interest.

\section{References}

1. Mujabar, P.S.; Chandrasekar, N. Shoreline change analysis along the coast between Kanyakumari and Tuticorin of India using remote sensing and GIS. Arab. J. Geosci. 2011, 6, 647-664. [CrossRef]

2. Huang, X. Resource Economics; Nanjing University Press: Nanjing, China, 2010; Volume 1-3.

3. Hou, X.; Liu, J.; Song, Y.; Li, X. Environmental-ecological Effect of Development and Utilization of China's Coastline and Policy Recommendations. Bull. Chin. Acad. Sci. 2016, 31, 1143-1150.

4. Salmon, C.; Duvat, V.; Laurent, V. Human- and climate-driven shoreline changes on a remote mountainous tropical Pacific Island: Tubuai, French Polynesia. Anthropocene 2019, 25, 100191. [CrossRef]

5. List, J.H.; Farris, A.; Sullivan, C.M. Reversing storm hotspots on sandy beaches: Spatial and temporal characteristics. Mar. Geol. 2006, 226, 261-279. [CrossRef]

6. Umar, Z.; Akib, W.A.A.W.M.; Ahmad, A. Monitoring shoreline change using Remote sensing and GIS: A case study of padang coastal area, Indonesia. In Proceedings of the IEEE 9th International Colloquium on Signal Processing and its Applications, Kuala Lumpur, Malaysia, 8-10 March 2013; pp. 280-284. [CrossRef] 
7. Ranasinghe, R.; Duong, T.M.; Uhlenbrook, S.; Roelvink, D.; Stive, M.J.F. Climate-change impact assessment for inlet-interrupted coastlines. Nat. Clim. Chang. 2012, 3, 83-87. [CrossRef]

8. Liao, T.; Cai, T.; Liu, Y.; Xia, X. Continental shoreline change in Zhejiangduringthe last one hundred years. J. Mar. Sci 2016, 34, 25-33.

9. Wang, B.; Liang, L.; Hui, F.; Cheng, X.; Gong, P.; Chen, Z.; Huang, H. Spatiotemporal changes of the Chinese coastlines: Landsat imagery from 1975 to 2015. J. Beijing Norm. Univ. Nat. Sci. 2019, 55, 83-100.

10. Sun, X.; Wu, M.; Tian, J.; Lu, J.; Yu, H.; Song, F.; Liang, F. Driving forces and spatio-temporal variation of Weihai coastline in recent 30 years. J. Appl. Oceanogr. 2019, 38, 206-213.

11. Li, J.; Ye, M.; Pu, R.; Liu, Y.; Guo, Q.; Feng, B.; Huang, R.; He, G. Spatiotemporal Change Patterns of Coastlines in Zhejiang Province, China, Over the Last Twenty-Five Years. Sustainability 2018, 10, 477. [CrossRef]

12. Switzer, A.D.; Sloss, C.R.; Horton, B.P.; Zong, Y.Q. Preparing for coastal change Introduction. Quat. Sci. Rev. 2012, 54, 1-3. [CrossRef]

13. Yan, Y.; Zhang, Z.; Wang, C.; Zhang, L.; Huang, Y.; Zhang, J. Analysis of recent coastline evolution due to marine reclamation projects in the Qinzhou Bay. Pol. Marit. Res. 2017, 24, 188-194. [CrossRef]

14. Sener, E.; Davraz, A.; Şener, S. Investigation of Aksehir and Eber Lakes (SW Turkey) Coastline Change with Multitemporal Satellite Images. Water Resour. Manag. 2009, 24, 727-745. [CrossRef]

15. Zhu, G.; Xu, X. Annual Processes of Land Reclamation from the Sea Along the Northwest Coast of Bohai Bay During 1974 to 2010. Sci. Geogr. Sin. 2012, 32, 1006-1012.

16. Alesheikh, A.A.; Ghorbanali, A.; Nouri, N. Coastline change detection using remote sensing. Int. J. Environ. Sci. Technol. 2007, 4, 61-66. [CrossRef]

17. Moore, L.J. Shoreline mapping techniques. J. Coast. Res. 2000, 16, 111-124.

18. Saleem, A.; Awange, J. Coastline shift analysis in data deficient regions: Exploiting the high spatio-temporal resolution Sentinel-2 products. Catena 2019, 179, 6-19. [CrossRef]

19. Nassar, K.; Fath, H.; Mahmod, W.E.; Masria, A.; Nadaoka, K.; Negm, A. Automatic detection of shoreline change: Case of North Sinai coast, Egypt. J. Coast. Conserv. 2018, 22, 1057-1083. [CrossRef]

20. Pradhan, B.; Rizeei, H.M.; Abdulle, A. Quantitative Assessment for Detection and Monitoring of Coastline Dynamics with Temporal RADARSAT Images. Remote Sens. 2018, 10, 1705. [CrossRef]

21. Liu, H.; Jezek, K.C. Automated extraction of coastline from satellite imagery by integrating Canny edge detection and locally adaptive thresholding methods. Int. J. Remote Sens. 2004, 25, 937-958. [CrossRef]

22. He, B.-J.; Zhao, Z.-Q.; Shen, L.-D.; Wang, H.-B.; Li, L.-G.; He, B.-J. An approach to examining performances of $\mathrm{cool} /$ hot sources in mitigating/enhancing land surface temperature under different temperature backgrounds based on landsat 8 image. Sustain. Cities Soc. 2019, 44, 416-427. [CrossRef]

23. Li, X.; Damen, M.C. Coastline change detection with satellite remote sensing for environmental management of the Pearl River Estuary, China. J. Mar. Syst. 2010, 82, S54-S61. [CrossRef]

24. Mishra, M.; Chand, P.; Pattnaik, N.; Kattel, D.B.; Panda, G.K.; Mohanti, M.; Baruah, U.D.; Chandniha, S.K.; Achary, S.; Mohanty, T. Response of long- to short-term changes of the Puri coastline of Odisha (India) to natural and anthropogenic factors: A remote sensing and statistical assessment. Environ. Earth Sci. 2019, 78, 338. [CrossRef]

25. Kale, M.M.; Ataol, M.; Tekkanat, I.S. Assessment of shoreline alterations using a Digital Shoreline Analysis System: A case study of changes in the Yeşilırmak Delta in northern Turkey from 1953 to 2017. Environ. Monit. Assess. 2019, 191, 398. [CrossRef] [PubMed]

26. Thoai, D.T.; Dang, A.N.; Oanh, N.T.K. Analysis of coastline change in relation to meteorological conditions and human activities in Ca mau cape, Viet Nam. Ocean Coast. Manag. 2019, 171, 56-65. [CrossRef]

27. Wu, X.; Liu, C.; Wu, G. Spatial-Temporal Analysis and Stability Investigation of Coastline Changes: A Case Study in Shenzhen, China. IEEE J. Sel. Top. Appl. Earth Obs. Remote Sens. 2018, 11, 45-56. [CrossRef]

28. Kuleli, T.; Guneroglu, A.; Karsli, F.; Dihkan, M. Automatic detection of shoreline change on coastal Ramsar wetlands of Turkey. Ocean Eng. 2011, 38, 1141-1149. [CrossRef]

29. Romine, B.M.; Fletcher, C.; Frazer, L.; Genz, A.S.; Barbee, M.; Lim, S.-C. Historical Shoreline Change, Southeast Oahu, Hawaii; Applying Polynomial Models to Calculate Shoreline Change Rates. J. Coast. Res. 2009, 256, 1236-1253. [CrossRef]

30. Ashton, A.; Donnelly, J.P.; Evans, R.L. A discussion of the potential impacts of climate change on the shorelines of the Northeastern USA. Mitig. Adapt. Strat. Glob. Chang. 2007, 13, 719-743. [CrossRef] 
31. Klein, M.; Lichter, M. Monitoring changes in shoreline position adjacent to the Hadera power station, Israel. Appl. Geogr. 2006, 26, 210-226. [CrossRef]

32. Robertson, W.; Zhang, K.; Whitman, D. Hurricane-induced beach change derived from airborne laser measurements near Panama City, Florida. Mar. Geol. 2007, 237, 191-205. [CrossRef]

33. Ruggiero, P.; Buijsman, M.; Kaminsky, G.M.; Gelfenbaum, G. Modeling the effects of wave climate and sediment supply variability on large-scale shoreline change. Mar. Geol. 2010, 273, 127-140. [CrossRef]

34. Kermani, S.; Boutiba, M.; Guendouz, M.; Guettouche, M.S.; Khelfani, D. Detection and analysis of shoreline changes using geospatial tools and automatic computation: Case of jijelian sandy coast (East Algeria). Ocean Coast. Manag. 2016, 132, 46-58. [CrossRef]

35. Ciritci, D.; Turk, T. Automatic Detection of Shoreline Change by Geographical Information System (GIS) and Remote Sensing in the Göksu Delta, Turkey. J. Indian Soc. Remote Sens. 2019, 47, 233-243. [CrossRef]

36. Ozturk, D.; Beyazit, I.; Kilic, F. Spatiotemporal Analysis of Shoreline Changes of the Kizilirmak Delta. J. Coast. Res. 2015, 316, 1389-1402. [CrossRef]

37. Mentaschi, L.; Vousdoukas, M.; Pekel, J.-F.; Voukouvalas, E.; Feyen, L. Global long-term observations of coastal erosion and accretion. Sci. Rep. 2018, 8, 12876. [CrossRef]

38. Zhang, Y.; Hou, X. Characteristics of Coastline Changes on Southeast Asia Islands from 2000 to 2015. Remote Sens. 2020, 12, 519. [CrossRef]

39. Storlazzi, C.; Gingerich, S.B.; Van Dongeren, A.; Cheriton, O.M.; Swarzenski, P.W.; Quataert, E.; Voss, C.; Field, D.W.; Annamalai, H.; Piniak, G.A.; et al. Most atolls will be uninhabitable by the mid-21st century because of sea-level rise exacerbating wave-driven flooding. Sci. Adv. 2018, 4, eaap9741. [CrossRef]

40. Giardino, A.; Nederhoff, K.; Vousdoukas, M. Coastal hazard risk assessment for small islands: Assessing the impact of climate change and disaster reduction measures on Ebeye (Marshall Islands). Reg. Environ. Chang. 2018, 18, 2237-2248. [CrossRef]

41. Dedekorkut-Howes, A.; Torabi, E.; Howes, M. When the tide gets high: A review of adaptive responses to sea level rise and coastal flooding. J. Environ. Plan. Manag. 2020, 1-42. [CrossRef]

42. Romine, B.M.; Fletcher, C. A Summary of Historical Shoreline Changes on Beaches of Kauai, Oahu, and Maui, Hawaii. J. Coast. Res. 2013, 288, 605-614. [CrossRef]

43. Connell, J. Losing ground? Tuvalu, the greenhouse effect and the garbage can. Asia Pac. Viewp. 2003, 44, 89-107. [CrossRef]

44. Collen, J.; Garton, D.W.; Gardner, J.P.A. Shoreline Changes and Sediment Redistribution at Palmyra Atoll (Equatorial Pacific Ocean): 1874-Present. J. Coast. Res. 2009, 253, 711-722. [CrossRef]

45. Sandhyavitri, A.; Fatnanta, F.; Husaini, R.R.; Suprayogi, I. Combination of a Coastal Vulnerability Index (CVI) and social economic approaches in prioritizing the development of Riau Coastlines, Indonesia. In Proceedings of the MATEC Web of Conferences, Bali, Indonesia, 24-25 October 2018; EDP Sciences: Les Ulis, France, 2019; Volume 276, p. 02006.

46. Reese, S.; Cousins, W.J.; Power, W.L.; Palmer, N.G.; Tejakusuma, I.G.; Nugrahadi, S. Tsunami vulnerability of buildings and people in South Java-Field observations after the July 2006 Java tsunami. Nat. Hazards Earth Syst. Sci. 2007, 7, 573-589. [CrossRef]

47. Borrero, J.C. Field Survey of Northern Sumatra and Banda Aceh, Indonesia after the Tsunami and Earthquake of 26 December 2004. Seism. Res. Lett. 2005, 76, 312-320. [CrossRef]

48. Saatcioglu, M.; Ghobarah, A.; Nistor, I. Performance of Structures in Indonesia during the December 2004 Great Sumatra Earthquake and Indian Ocean Tsunami. Earthq. Spectra 2006, 22, 295-319. [CrossRef]

49. Borrero, J.C.; Weiss, R.; Okal, E.A.; Hidayat, R.; Arcas, D.; Titov, V. The tsunami of 2007 September 12, Bengkulu province, Sumatra, Indonesia: Post-tsunami field survey and numerical modelling. Geophys. J. Int. 2009, 178, 180-194. [CrossRef]

50. Paulik, R.; Gusman, A.; Williams, J.H.; Pratama, G.M.; Lin, S.-L.; Prawirabhakti, A.; Sulendra, K.; Zachari, M.Y.; Fortuna, Z.E.D.; Layuk, N.B.P.; et al. Tsunami Hazard and Built Environment Damage Observations from Palu City after the September 282018 Sulawesi Earthquake and Tsunami. Pure Appl. Geophys. 2019, 176, 3305-3321. [CrossRef]

51. Marfai, M.A.; Almohamad, H.; Dey, S.; Susanto, B.; King, L. Coastal dynamic and shoreline mapping: Multi-sources spatial data analysis in Semarang Indonesia. Environ. Monit. Assess. 2007, 142, 297-308. [CrossRef] 
52. Dewi, R.S.; Bijker, W. Dynamics of shoreline changes in the coastal region of Sayung, Indonesia. Egypt. J. Remote Sens. Space Sci. 2019. [CrossRef]

53. Julzarika, A. Utilization of LAPAN Satellite (TUBSAT, A2, and A3) in supporting Indonesia's potential as maritime center of the world. In 3rd International Symposium on Lapan-Ipb Satellite for Food Security and Environmental Monitoring 2016; Setiawan, Y., Ed.; Iop Publishing Ltd.: Bristol, UK, 2017; Volume 54.

54. Yu, C.; Wang, J.; Xu, J.; Peng, R.; Cheng, Y.; Wang, M. Advance of Coastline Extraction Technology. J. Geomat. Sci. Technol. 2014, 31, 305-309.

55. Esmail, M.; Mahmod, W.E.; Fath, H. Assessment and prediction of shoreline change using multi-temporal satellite images and statistics: Case study of Damietta coast, Egypt. Appl. Ocean Res. 2019, 82, 274-282. [CrossRef]

56. Zhou, M.; Wu, M.; Zhang, G.; Zhao, L.; Hou, X.; Yang, Y. Analysis of Coastal Zone Data of Northern Yantai Collected by Remote Sensing from 1990 to 2018. Appl. Sci. 2019, 9, 4466. [CrossRef]

57. Deng, S. ENVI Remote Sensing Image Processing Method; Higher Education Press: Beijing, China, 2014.

58. McFeeters, S.K. The use of the Normalized Difference Water Index (NDWI) in the delineation of open water features. Int. J. Remote Sens. 1996, 17, 1425-1432. [CrossRef]

59. Otsu, N. A Threshold Selection Method from Gray-Level Histograms. IEEE Trans. Syst. Man Cybern. 1979, 9, 62-66. [CrossRef]

60. Liu, B.; Meng, W.; Zhao, J.; Hu, B.; Liu, L.; Zhang, F. Variation of Coastline Resources Utilization in China from 1990 to 2013. J. Nat. Resour. 2015, 30, 2033-2044.

61. Hou, X.; Wu, T.; Wang, Y.; Xu, X.; Chen, Q.; Yu, L. Extraction and accuracy evaluation of multi-temporal coastl-ines of mainland China since 1940s. Mar. Sci. 2014, 38, 66-73.

62. Suo, A.; Cao, K.; Ma, H.; Wang, Q.; Yu, Y. Discussion on Classification System of Coastline. Sci. Geogr. Sin. 2015, 35, 933-937.

63. Sun, W.; Ma, Y.; Zhang, J.; Liu, S.; Ren, G. Study of Remote Sensing Interpretation Keys and Extraction Technique of Different types of Shoreline. Bull. Surv. Mapp. 2011, 41-44.

64. Ge, X.; Sun, X.; Liu, Z. Object-oriented coastline classification and extraction from remote sensing imagery. In Remote Sensing of the Environment: 18th National Symposium on Remote Sensing of China; Tong, Q., Shan, J., Zhu, B., Eds.; Spie-Int Soc Optical Engineering: Bellingham, WA, USA, 2014; Volume 9158. [CrossRef]

65. Wu, T.; Hou, X.; Xu, X. Spatio-temporal characteristics of the mainland coastline utilization degree over the last 70 years in China. Ocean Coast. Manag. 2014, 98, 150-157. [CrossRef]

66. Wu, C. An Analysis of the Rise of Indonesia's Economy and the Challenges it Faces; Crossroads Southeast Asian Studies: Guangxi, China, 2013.

67. Torresan, S.; Critto, A.; Valle, M.D.; Harvey, N.; Casini, M. Assessing coastal vulnerability to climate change: Comparing segmentation at global and regional scales. Sustain. Sci. 2008, 3, 45-65. [CrossRef]

68. Rao, K.N.; Subraelu, P.; Rao, T.V.; Malini, B.H.; Ratheesh, R.; Bhattacharya, S.; Rajawat, A.S. Ajai Sea-level rise and coastal vulnerability: An assessment of Andhra Pradesh coast, India through remote sensing and GIS. J. Coast. Conserv. 2008, 12, 195-207. [CrossRef]

69. Yin, J.; Yin, Z.; Wang, J.; Xu, S. National assessment of coastal vulnerability to sea-level rise for the Chinese coast. J. Coast. Conserv. 2012, 16, 123-133. [CrossRef]

70. Islam, A.; Mitra, D.; Dewan, A.; Akhter, S.H. Coastal multi-hazard vulnerability assessment along the Ganges deltaic coast of Bangladesh-A geospatial approach. Ocean Coast. Manag. 2016, 127, 1-15. [CrossRef]

71. Zhang, K.; Douglas, B.C.; Leatherman, S.P. Global Warming and Coastal Erosion. Clim. Chang. 2004, 64, 41-58. [CrossRef]

72. Lentz, E.; Thieler, E.; Plant, N.G.; Stippa, S.R.; Horton, R.M.; Gesch, D. Evaluation of dynamic coastal response to sea-level rise modifies inundation likelihood. Nat. Clim. Chang. 2016, 6, 696-700. [CrossRef]

73. Watson, C.S.; White, N.J.; Church, J.A.; King, M.; Burgette, R.J.; Legresy, B. Unabated global mean sea-level rise over the satellite altimeter era. Nat. Clim. Chang. 2015, 5, 565-568. [CrossRef]

74. Domingues, C.; Church, J.A.; White, N.J.; Gleckler, P.J.; Wijffels, S.E.; Barker, P.M.; Dunn, J.R. Improved estimates of upper-ocean warming and multi-decadal sea-level rise. Nature 2008, 453, 1090-1093. [CrossRef]

75. Borrero, J.C. Field Data and Satellite Imagery of Tsunami Effects in Banda Aceh. Science 2005, 308, 1596. [CrossRef]

76. Marfai, M.A.; King, L. Monitoring land subsidence in Semarang, Indonesia. Environ. Earth Sci. 2007, 53, 651-659. [CrossRef] 
77. Murdiyarso, D.; Purbopuspito, J.; Kauffman, J.B.; Warren, M.; Sasmito, S.D.; Donato, D.C.; Manuri, S.; Krisnawati, H.; Taberima, S.; Kurnianto, S. The potential of Indonesian mangrove forests for global climate change mitigation. Nat. Clim. Chang. 2015, 5, 1089-1092. [CrossRef]

78. Wang, J.; Sui, L.; Yang, X.; Wang, Z.; Liu, Y.; Kang, J.; Lu, C.; Yang, F.; Liu, B. Extracting Coastal Raft Aquaculture Data from Landsat 8 OLI Imagery. Sensors 2019, 19, 1221. [CrossRef] [PubMed]

79. Wang, Z.; Yang, X.; Su, F.; Zhang, H.; Yan, F.; Zhang, J. Remote Sensing Application in China's Coastal Zones and Islands: Recent Progress and Some Suggestions. Chin. J. Eng. Sci. 2019, 21, 59-63. [CrossRef]

80. Wang, Z.; Yang, X.; Liu, Y.; Lu, C. Extraction of coastal raft cultivation area with heterogeneous water background by thresholding object-based visually salient NDVI from high spatial resolution imagery. Remote Sens. Lett. 2018, 9, 839-846. [CrossRef]

81. Wang, Z.; Yang, X.; Lü, C.; Yang, F. A scale self-adapting segmentation approach and knowledge transfer for automatically updating land use/cover change databases using high spatial resolution images. Int. J. Appl. Earth Obs. Geoinf. 2018, 69, 88-98. [CrossRef]

82. Lü, C.; Yang, X.; Wang, Z.; Li, Z. Using multi-level fusion of local features for land-use scene classification with high spatial resolution images in urban coastal zones. Int. J. Appl. Earth Obs. Geoinf. 2018, 70, 1-12. [CrossRef]

(C) 2020 by the authors. Licensee MDPI, Basel, Switzerland. This article is an open access article distributed under the terms and conditions of the Creative Commons Attribution (CC BY) license (http://creativecommons.org/licenses/by/4.0/). 